Article

\title{
Site-Specific Determinants and Remains of Medieval City Fortifications as the Potential for Creating Urban Greenery Systems Based on the Example of Historical Towns of the Opole Voivodeship
}

\author{
Katarzyna Łakomy (D)
}

check for

updates

Citation: Łakomy, K. Site-Specific Determinants and Remains of Medieval City Fortifications as the Potential for Creating Urban Greenery Systems Based on the Example of Historical Towns of the Opole Voivodeship. Sustainability 2021, 13, 7032. https://doi.org/ $10.3390 /$ su13137032

Academic Editors: Jan K. Kazak,

Katarzyna Hodor and

Magdalena Wilkosz-Mamcarczyk

Received: 25 April 2021

Accepted: 17 June 2021

Published: 23 June 2021

Publisher's Note: MDPI stays neutral with regard to jurisdictional claims in published maps and institutional affiliations.

Copyright: (C) 2021 by the author. Licensee MDPI, Basel, Switzerland. This article is an open access article distributed under the terms and conditions of the Creative Commons Attribution (CC BY) license (https:// creativecommons.org/licenses/by/ $4.0 /)$.
Chair of Landscape Architecture, Faculty of Architecture, Cracow University of Technology CUT, Warszawska 24, 31-155 Kraków, Poland; klakomy@pk.edu.pl

\begin{abstract}
The article discusses the natural and historic heritage of medieval towns in the Opole Silesia region in the context of their ability to take advantage of their potential for sustainable development, especially in tourism. The chosen environmental, urban, architectural, and landscape factors were compared through this aspect and subjected to a multidimensional comparative analysis. The research studies applied mostly archival materials, contemporary topographic maps, statistical data, and both landscape as well as urban field studies. As a result, the studies indicated that the natural conditions of the locations, the preservation level of the urban system along with its development trends, and the areas of the old fortifications with their accompanying greenery constitute these towns' very value and identity. As they combine elements of nature and culture, they may serve as the basis for development of tourism, which is likely to contribute to the social and economic revitalization of the region itself. What may play a major role in the quest for sustainable development are the urban greenery systems to be designed based on former fortification areas, city greenery, and natural environmental resources, which have been integral elements of these towns over many past centuries.
\end{abstract}

Keywords: cultural heritage; medieval town planning; city defence walls; monument conservation; historical greenery; urban greenery system; landscape ecology; Silesian city; Opole Voivodeship

\section{Introduction}

Cultural heritage management is a fundamental part of preserving its value for future generations. Apart from obvious values, it is a universal value that shapes the identity and awareness of society. It also defines its wealth and can become a basis for important initiatives as well as socio-economic transitions. What is key is that when faced with contemporary social, economic, and ecological problems of cities, it can become a part of sustainability strategies. However, the total sum of our heritage assets constantly fluctuates and many sites lose their values, while many others remain unidentified and unstudied [1]. In the Polish system of monument protection, there is also a problem with specifying the rank of a monument on the scale of a municipality, voivodeship and the country overall, which is associated with equal allocation of funds for their renovation. On the other hand, Poland does not possess a unified system of valuating heritage elements, including architectural, archaeological, or garden design monuments [2]. Many scholars currently pursue the establishment of such a system, with ICOMOS Polska playing a leadership role $[3,4]$.

In this context, a group of small, poorly explored towns located in the Opole Voivodeship was noted. And they became the main subject of research. Selected out of the total pool of 36 towns in the voivodeship, selection was based on several criteria: their medieval origins, featuring a regular quadrangle-like market square, an oval layout, as well as the presence of former brick fortification walls (total of 15 towns). 
Their local character, along with the region's specificity, means this heritage is underappreciated and underused in the region's development and its socio-economic context. Initial landscape and urban planning investigation provided a general overview of these towns as a system of specific forms of cultural heritage linked with the hydrological network, natural habitats, and agricultural areas.

A variety of materials were applied in the research study; however, the most important ones used for comparative analysis were archival plans and city views in addition to contemporary topographic data, data collected during field research, as well as statistical data.

In the context of further research, our intent was also to determine the degree to which decisions associated with a historical founding of a town can carry over to its contemporary functioning and its development potential in the context of sustainable development. Therefore, during the research, these issues were characterized: wildlife factors that historically defined the founding of the towns under study during the Middle Ages, assess the impact on their spatial form and development, and contemporarily-to isolate place-based landscape assets and the potential to use them to create urban greenery systems. The primary objective was to create a framework of principles for the design of such systems based on a major element-historical post-fortress areas along with guidelines of their refurbishment and directions of further study.

Building linkages between nature and the manmade environment has long since been a field of investigation for scholars and designers. The genesis of introducing greenery into cities dates back to ancient times [5,6]. Certainly, we can point to nineteenth-century proposals of American parkways, followed by Howard's garden-cities [7], which transformed into concepts of continuous systems like greenways and green belts [6] as precursory efforts in treating greenery in a systemic manner. City greenery systems can be divided into: strip, wedge, radial, and mixed layouts $[6,8]$. Significant changes in creating urban greenery systems were affected by the concept of ecological patches and corridors by Forman and Gordon $[9,10]$. They assume a continuity of environmental linkages and their significance to environmental balance, biodiversity, and the self-renewal of ecosystems [11]. Green infrastructure is a contemporary concept that implies a strategically planned network of natural and semi-natural areas that perform social and economic function, but most importantly, they support biodiversity [12].

Creating urban greenery systems based on areas around fortifications became popular in the nineteenth and at the turn of the twentieth century, when, in the face of urban development and a desire to improve health conditions in cities, large-scale demolition of medieval and modern fortifications was carried out. The most prominent examples of this include: Vienna, Brno, Salzburg, Olomouc, or Cologne [13], while Polish cases feature Wrocław [14] or Gdańsk [8]. The work initiated in Kraków in 1822 was one of the first ever in Europe and was based on transforming the decayed areas of former fortifications into a public strolling park surrounding the Old Town, so-called Planty Park [15].

In the contemporary reality of Polish heritage conservation, there is a lack of comprehensive studies of the development of greenery in areas previously occupied by medieval city fortifications. There are also no guidelines as to their design and arrangement or maintenance and renovation. The role of fortifications as objects of high landscape values was first noted in Poland by Bogdanowski [16]. His research is continued by K. Wielgus, J. Środulska-Wielgus, and A. Staniewska of the Cracow University of Technology [17]. This landscape and fortification structures from the Middle Ages, as attractions of cultural tourism, were analysed by Armin Mikos von Rohrscheidt [18] and J. Środulska-Wielgus [19]. The subject of greenery at the city walls was taken up in a historical $[20,21]$ or comparative $[22,23]$ context. It is worth noting that many cities have studies on greenery and urban planning, created for the purposes of land development studies or the needs of conservation protection.

The multi-volume publication by Bimler [24], which was followed by Przyłęcki's work [25], are considered to be among seminal works on the history of the massive buildings of medieval cities of Silesia. Among the important publications in the field of archi- 
tecture, urban planning, and art, Thullie [26] and Chrzanowski and Kornecki [27] can be mentioned. Adamska [28] dealt in detail with the town squares of Opole Silesia. Few scholars have so far become narrowly specialised in medieval city walls. A comparative analysis of such structures in Silesia and the Opole Voivodeship, combined with assessments of their state of preservation, was provided by Piechaczek [29] and Przybyłok [30]. Legendziewicz is carrying out extensive work on Medieval town gates (Głubczyce, Głuchołazy, Grodków, Namysłów, Prudnik, Głogówek [31-33]) and walls (among others Kluczbork [34] or Grodków [35]) in Silesia.

The conservation of fortifications that are a part of a town's urban fabric is an important matter, as is the pursuit of new functions for historical defensive structures and the potential to adapt them based on the development directions of modern cities. The role of fortifications, including greenery, in the space of the city was discussed in the multi-author book 'Fortyfikacje w przestrzeni miasta' [36], while the issues of the conservation and exhibition of fortifications in Lower Silesia were widely discussed by Przyłęcki [37]. The state of preservation and the problems of revitalising selected medieval towns of the Opole Voivodeship were explored by Adamska [38].

Here, we should also mention studies associated with ICOMOS Polska, which resulted in numerous academic conferences, monographs, and best practices handbooks [39]. They discussed research and adaptation methodologies [40], as well as management in the context of sustainability. Scholars note that the proper assignation of functions to such structures is a major contemporary challenge, and determines the scope of necessary procedures while allowing for tourist access [41].

The architectural and urban heritage of the Opole Voivodship, as noted by scholars [28], has been explored to a varying degree and there is a lack of comprehensive investigations. The state of research concerning individual towns presents itself betterPaczków [42,43], Otmuchów [43], Opole [44], Namysłów [45], Biała [46], Byczyna [47], Głogówek [48], Głubczyce [49], Kluczbork [50], Krapkowice [51], Ujazd [52]. This is, of course, an incomplete list. Pre-war publications and chronicles, unpublished documents, historical files of each town or historical and urban planning studies drafted for land development studies or architectural conservation are additional sources of knowledge [53]. Their precision and volume nevertheless exceed the bounds of this paper.

The number of military architecture specimens in Poland is small. According to data provided by the NID, monuments of this type constitute $1.56 \%$ of all structures entered into the monuments register in Polish territory. They include city walls and gates, castle and defensive manor fortifications, fortresses and their elements, bunkers, shelters, guardhouses, fortified positions, etc. This group includes 1105 structures dated to between the Middle Ages and the Second World War. They typically have considerable historical value and are associated with major events in the country's history [1].

The town of Paczków, located in the Opole Voivodeship, is one of the highest-class structures of this type in Poland (Figure 1). Both the fortification system and the urban layout that it surrounds have been entered in the monuments register. Labelled as 'Paczków-old-town complex with a medieval fortification system', it was also placed on the list of Monuments to History [54]. It is one of the best examples of medieval urban planning Silesian towns $[43,55]$, which were present in the territory of historical Silesia $[56,57]$ and the present-day Śląsk, Górny Ślask, and Opole Voivodeship. 

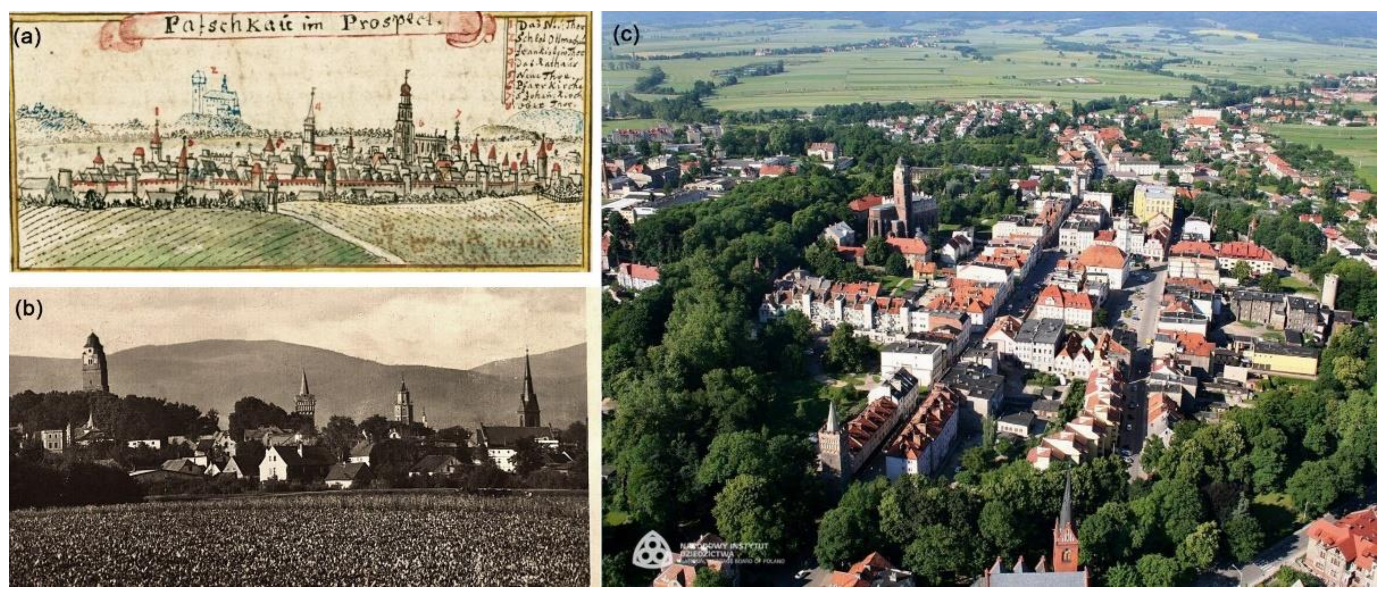

Figure 1. Case study-Paczków (Patschkau), (a) View of the city (ca. middle eighteenth century, W.B. Werner (source: https: / / www.bibliotekacyfrowa.pl/dlibra/publication/8092/edition/15414, accessed on 15 October 2020), (b) View of the city (1935-1940) (source: https://polska-org.pl/3478452,foto.html?idEntity=536159, accessed on 15 October 2020), (c) Current bird's eye view (source: https:/ /zabytek.pl/pl/obiekty/paczkow-zespol-staromiejski-ze-sredniowiecznymsystemem-fortyfik, accessed on 12 April 2021).

The Opole Voivodeship is the smallest of Poland's sixteen voivodeships. It was established in 1950, and has been functioning in its current form since 1999. It is located between two strong voivodeships: the Silesian Voivodeship and the Lower Silesian Voivodeship, with which it is historically and culturally tied. From the south, it borders the Czech Republic. It has an area of $9412 \mathrm{~km}^{2}$ and occupies only $3 \%$ of the country's territory. It has a population of 980,771 [58] and an agrarian character.

The Opole Voivodeship's authorities, as well as those of its individual municipalities and powiats, face numerous socio-economic issues: growing unemployment, waste management, a significant burden being placed on the environment by particulate matter and gas emissions, a transformation of its economic structure, planning decisions, and others (based on a GUS analysis). A GIOŚ report from 2020 clearly indicated that the greatest threat to the environment of this region still included the unsatisfactory quality of its waters, air pollution with particulate matter, benzo[a]pyrene, and excessive noise levels [59].

At present, local strategic plans-the Voivodeship Development Strategy and the Environmental Protection Programme-are at the drafting stage. In the context of the subject under study, previous documents featured clearly identified priority goals, which included both improving the condition of the natural environment and citizens' quality of life, as well as the region's economic activation, based on its existing predispositions, resources, and wildlife and landscape assets and their reserves [60].

In the context of efforts towards achieving the 17 Goals of Sustainable Development, the Sustainable Development Report 2020 placed Poland in 24th place [61]. However, as demonstrated by Kapera in a study on the implementation of sustainable development in the country published in 2018, the Opole Voivodeship ranked last [62].

Voivodeship tourism potential studies performed in 2008 ranked voivodeships in terms of a taxonomic tourist attractivity indicator [63]. In this ranking, the Opole Voivodeship placed last. In 2015, it also placed last in terms of the taxonomic development indicator score (taksonomiczny miernik rozwoju, TMR) [64]. Furthermore, in terms of tourism geography, it was observed that Opolszczyzna has a poor tourism and cultural potential [65].

In light of the above, my study could support strategic decisions for the region, whose developmental perspectives should be based on broad action and change in the fields of economic development and environmental protection. This action can be based on its strengths, which also act as its fundamental assets from the perspective of tourism potential [66,67] -its historical cultural landscape of medieval towns and their accompanying areas [68]. 
This is why among all the identifiers of the towns under study, I chose research categories linked to historical landscape elements, which are of key significance to the contemporary state of cultural and natural heritage: town placement determinants, urban layouts and linkage networks between them, city fortifications, landscaped and natural greenery, as well as the composition of their skylines.

It was demonstrated that site-specific defensive determinants affected the contemporary state of the towns' development, and hindering development conditions allowed for retaining reserves of land of high environmental potential.

The assessment of the state of preservation and the quality of individual town layout elements showed that they were assets of high tourism value (wildlife assets, cultural heritage assets, and a well-developed land and fluvial transport infrastructure). The remains of historical city fortifications were found to be a particularly significant element that can become not only an attractor, but also an element of a town's identification. These remains are not only walls, gates, or towers, but also the area of former embankments and moats-which are currently both landscaped areas and wastelands.

I determined that the state of preservation and quality of architectural and urban heritage, together with areas of natural and landscaped greenery can become a basis for creating elaborate greenery systems on the city scale and a linked ecological network on the regional scale. This could benefit not only the natural environment, but also the proper protection and exposition of cultural heritage and restore historical place-based identity. These can, in turn, lay the foundations for sustainable tourism.

\section{Materials and Methods}

\subsection{Research Side-Geographical Location, Environmentally Valuable Areas, Heritage Conservation}

The Opole Voivodeship is located in southwestern Poland at the point of contact of three geographical regions: the Silesian-Kraków Uplands, the Silesian Lowlands, and the Sudetes. The spatial form of these areas results in Opolszczyzna being a basin open towards the west, and whose central axis is the River Oder. It is the second-longest river in Poland. The histographic network is formed by its numerous confluences, of which the most significant ones are the Osobłoga, the Nysa Kłodzka, the Mała Panew, and the Stobrawa. The voivodeship's territory also features two large artificial water bodies: the Otmuchowskie and Turawskie lakes.

The terrain is shaped by the Racibórz Basin in the south-eastern section, the Sudetes Foothills in the southwest, the Chełm Mountain Chain and the Niemodlin Lowlands in the centre, and the Opole Lowlands in the remainder of the area. The tallest point in Opolszczyzna is Biskupia Kopa (890 m above sea level), which is located in the Opawskie Mountains [59].

In terms of landscape conservation areas, the voivodeship is ranked last in Poland [69]. There are no national parks here. The largest areas of protected greenery are landscape parks (with a combined area of 63 thousand ha) and protected landscape zones (196.3 thousand ha). However, in terms of percentage of occupied territory to total territory, this results in $6.7 \%$ for landscape parks and $20.8 \%$ for protected landscape zones, respectively. In total, areas protected under law account for $27.6 \%$ of the voivodeship's territory (based on GUS data, January 2021 [58]).

According to an NID report, the amount of items in the immovable monuments register of the voivodeship was 3152 (twelfth place in Poland), yet when calculated per $1000 \mathrm{~km}^{2}$, it placed the voivodeship in third place (right behind the Lower Silesian and Lesser Poland voivodeships) and amounted to 335 [1]. When compared against population, this number amounted to 3.2, which also placed the voivodeship in third place (right behind the Lubusz and Warmian-Masurian voivodeships). Defensive structures form an extraordinarily valuable, yet small $(1.56 \%)$ group of items in the country's monuments register-in the Opole Voivodeship, they account for only 48 entries out of the 878 sites in all of Poland. Urban layouts likewise are very few-in the Opole Voivodeship, there are 26 such listed heritage sites out of a total of 802 in Poland overall. 


\subsection{Methodology}

My study began with initial field analyses intended to reconnoitre the region in terms of its landscape and socio-economic conditions, and verify its cultural heritage assets. Description (state of preservation, dating, etc.) and formal analysis of urban layouts of cities, including the nature of medieval fortifications and urban green ensemble, has been made.

The data used in the study consisted of three groups: (1) Archival materials-both cartographic and iconographic-from the collection of the State Archives of Opole and Wrocław, the Library in Berlin and open repositories. The chief of these materials included: city plans from Christian Fredrich von Wrede's Kriegs-karte von Schlesien, from the years 1747-1753 [70], perspective views and city plans by Friedrich Bernhard Wernher from Silesia in Compendio seu Topographia [71]; his city panoramas are included in Scenographia urbum Silesiae [72] and a series of topographic maps from the Prussian Royal Measurement Office, the so-called Messtischblätter, drawn to a scale of 1:25,000 that had been published since 1875 (open repository). The second group of materials comprised GIS system data-a numerical terrain model, a land cover map, hydrographic maps, and CIR (Colour Infrared) orthophotomaps from "Opolskie w Internecie system informacji przestrzennej i portal informacyjno-promocyjny Województwa Opolskiego OWI-OGIS Portal (http:/ / maps. opolskie.pl/start/ accessed on 5 January 2021) along with supplementary elements from the Geoportal (www.geoportal.gov.pl, accessed on 5 January 2021). The third group consisted of material collected in the field-primarily photographic and graphical documentation.

Of the 36 cities and towns located within the voivodeship's administrative limits, 29 were determined to be of medieval origin. Among these, 25 were observed to be typical Silesian towns with oval outlines and a geometricised plan with a central, quadrate market square. Their town charters were issued in similar periods (the thirteenth and fourteenth centuries) and most (15) had city fortifications in the form of stone walls with gates and towers surrounded by an embankment or moat (Table 1, Figure 2).

Table 1. Preliminary elimination of towns of the Opole Voivodeship.

\begin{tabular}{|c|c|c|c|c|c|c|}
\hline $\begin{array}{l}\text { Total Number } \\
\text { of Towns in } \\
\text { the Opole } \\
\text { Voivodeship }\end{array}$ & $\begin{array}{c}\text { Towns of } \\
\text { Medieval } \\
\text { Origins }\end{array}$ & $\begin{array}{c}\text { Silesian Town } \\
\text { with a Central, } \\
\text { Quadrate } \\
\text { Market Square }\end{array}$ & $\begin{array}{l}\text { Town Charters } \\
\text { Issued in the } \\
\text { Thirteenth and } \\
\text { Fourteenth } \\
\text { Centuries }\end{array}$ & $\begin{array}{l}\text { Towns with } \\
\text { Documented } \\
\text { Medieval City } \\
\text { Fortifications }\end{array}$ & $\begin{array}{c}\text { Medieval } \\
\text { Fortifications } \\
\text { Absorbed by } \\
\text { Modern Ones }\end{array}$ & $\begin{array}{c}\text { Towns } \\
\text { Subjected to } \\
\text { Detailed } \\
\text { Analysis }\end{array}$ \\
\hline 36 & 29 & 25 & 25 & 18 & 3 & 15 \\
\hline
\end{tabular}

In order to make the evaluations of the towns, multidimensional comparative analysis was applied, based on the analysis of the results from the field studies, statistical data, the archival materials, and contemporary data obtained from the Geographical Information System (GIS). This allowed to develop methods for categorizing and evaluating the characteristics connected to the historic elements of the landscape, which, in turn, happen to be of key importance to today's cultural and natural heritage. What particularly matters is the context of applying the heritage potential to protection [73-76] and sustainable development. 


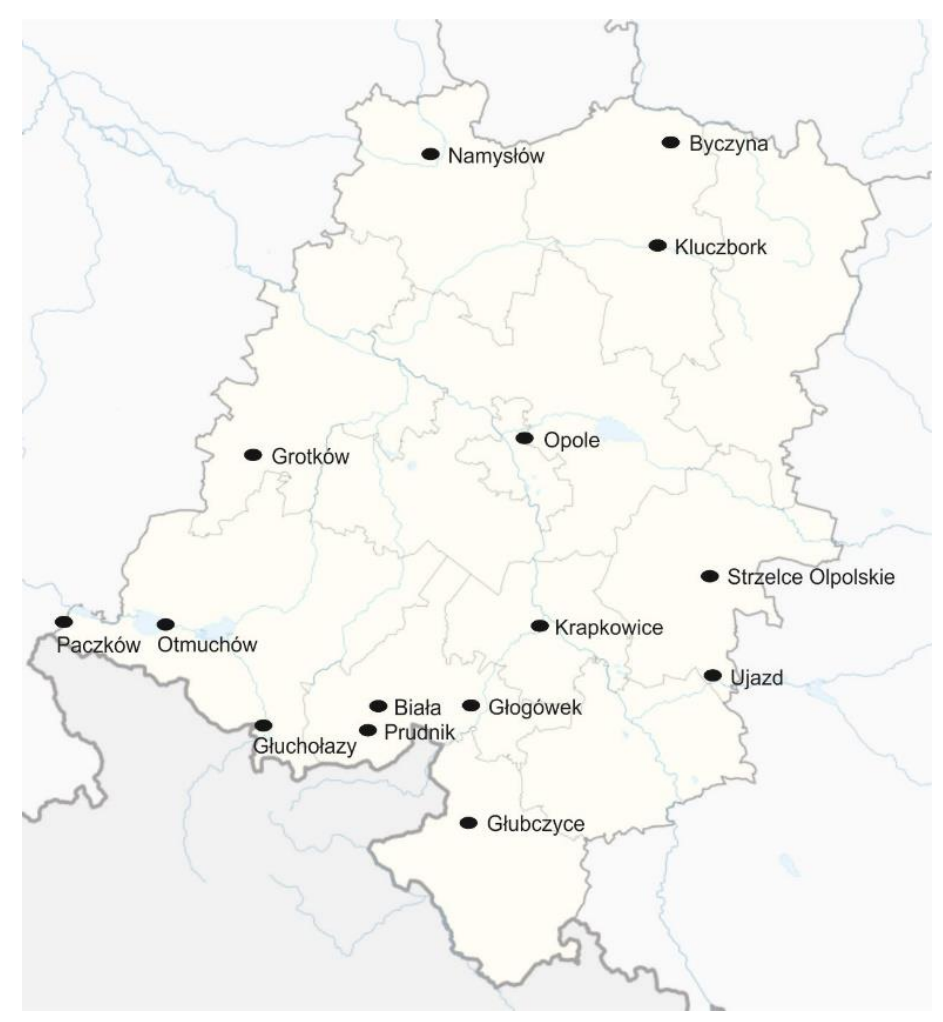

Figure 2. Outline of the Opole Voivodeship with towns subjected to detailed analysis.

The values (landscape values) of the surveyed centers were determined in the categories (indicators): environmental site-specific determinants, urban layout, city morphology, city fortifications, panoramas, and city greenery (Table 2).

These characteristics are the most distinctive for the physiognomy of these towns, essential both today and in the past, and they can be compared with historical cartography and iconography. In the author's opinion, they define the towns' respective identities and are their greatest value. The table below presents an outline of the actions taken. Indicator-originally isolated characteristics for the towns under study; historical significance-features the function and significance that a given indicator had in the past; contemporary significance-what we currently perceive as the indicator's value; valuethe element under assessment (Table 8); investigation-what was explored to determine the value of a given indicator.

On this basis, the results were obtained. Each town was analyzed against the criteria mentioned (a. Indicator) and then rated (d. Value) on a scale of $0-2$, where 0 denoted no value, and 2-the highest value. The sum of individual ratings denoted a town's individual cultural landscape potential (point 3.6). Landscaped greenery analyzes were carried out on the basis of identified: semi-natural greenery in river valleys, city parks, green squares, and public gardens within historical layouts, post-fortification areas converted into public greenery, post-fortification areas acting as wastelands, cemeteries, allotment gardens, block greenery, and other types (monasteries, hospitals, sports areas). The results are presented in Table 7 and then in Table 8. 
Table 2. Assessment indicators for historical towns of Opolian Silesia.

\begin{tabular}{|c|c|c|c|c|}
\hline a. Indicator & $\begin{array}{l}\text { b. Historical } \\
\text { Significance }\end{array}$ & $\begin{array}{l}\text { c. Contemporary } \\
\text { Significance }\end{array}$ & d. Value & e. Investigation \\
\hline $\begin{array}{l}\text { Environmental } \\
\text { site-specific } \\
\text { determinants }\end{array}$ & $\begin{array}{l}\text { Impact on site-specific } \\
\text { determinants }\end{array}$ & $\begin{array}{l}\text { Environmental and } \\
\text { landscape assets }\end{array}$ & Diversity & $\begin{array}{l}\text { hydrographic network, } \\
\text { wetlands, } \\
\text { hypsometric profile }\end{array}$ \\
\hline Urban layout & $\begin{array}{c}\text { Socio-legal, } \\
\text { organisational, } \\
\text { functional structure }\end{array}$ & $\begin{array}{c}\text { Fundamental } \\
\text { characteristic of a } \\
\text { layout }\end{array}$ & $\begin{array}{l}\text { Legibility of } \\
\text { urban layout and } \\
\text { structure }\end{array}$ & 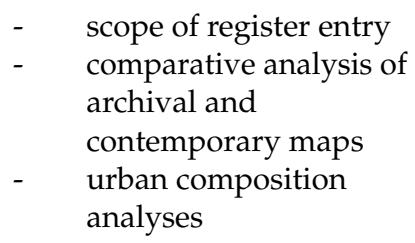 \\
\hline $\begin{array}{l}\text { City morphology } \\
\text { (development } \\
\text { directions) }\end{array}$ & $\begin{array}{c}\text { Socio-economic } \\
\text { development }\end{array}$ & $\begin{array}{c}\text { Determinant of } \\
\text { traditional landscape } \\
\text { retention }\end{array}$ & $\begin{array}{l}\text { Continuity of the } \\
\text { traditional } \\
\text { development } \\
\text { model }\end{array}$ & $\begin{array}{l}\text { - empirical method of } \\
\text { determining urban } \\
\text { transformation } \\
\text { trajectories }\end{array}$ \\
\hline City fortifications & $\begin{array}{l}\text { Defensibility, } \\
\text { exposition }\end{array}$ & $\begin{array}{l}\text { Elements of identity, } \\
\text { exposition }\end{array}$ & $\begin{array}{c}\text { State of } \\
\text { preservation }\end{array}$ & 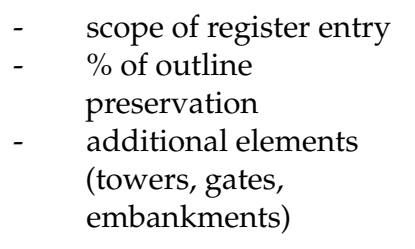 \\
\hline $\begin{array}{c}\text { Panoramas } \\
\text { (skyline composition) }\end{array}$ & $\begin{array}{l}\text { Informative symbol, } \\
\text { spatial orientation, a } \\
\text { sign of status and } \\
\text { wealth }\end{array}$ & Landscape asset & $\begin{array}{l}\text { Quality and state } \\
\text { of preservation- } \\
\text { legibility of } \\
\text { historical skyline } \\
\text { composition }\end{array}$ & 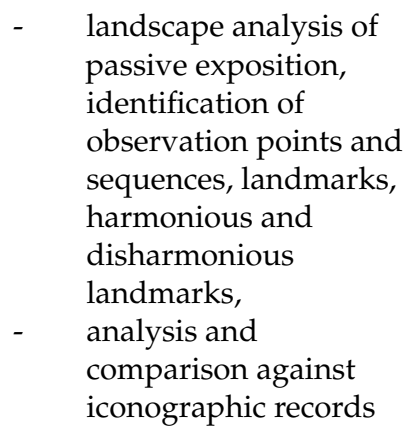 \\
\hline
\end{tabular}

\section{Results}

\subsection{Site-Specific Determinants of Historical Location}

Silesian towns were located on the basis of a developed model, e.g., the Magdeburg Law $[28,56]$. They were often founded In cruda radice, or their origins could be associated with the existence of earlier gords, villages, or market settlements, as well as ancient Roman and early medieval period settlement [56,77].

The primary determinants of selecting a site for settlement were: trade development potential, agricultural potential (trade and agricultural character), the location of centres of power or worship, and environmental determinants. This confirms the pan-European trends [78].

I found that the group of towns under study shared two primary founding factors, namely economic and environmental, which impacted each other. The first group includes trade-the network of pre-existing trade routes, whose genesis dates back to Roman times, and earlier, early medieval trade settlements. This was confirmed by contemporary studies 
of trade routes and the location of customs chambers in the region in the fourteenth, fifteenth, and sixteenth centuries [56,79]. Of key importance was the well-developed waterway network, as confirmed by historical maps of Silesia, i.e., by Helwig from 1561, wherein river transport acted as the main spatial linkage system.

Water, along with terrain typical of river valleys, was of fundamental significance to the shape and development of the towns under study. As many as $86 \%$ of them were founded near rivers-along the Oder and its confluences (the Nysa Kłodzka, the Biała, the Osobłoga, the Psina, the Prosna, the Stobrawa, the Ścinawa Niemodlińska, the Prudnik, the Kłodnica and the Struga Grodkowska) or in their immediate vicinity.

Most importantly, proximity to a river enhanced a settlement's defensibility, but was also of commercial and economic significance (fishing, fluvial transport, placement of water crossings, customs chambers, potential to build watermills, beer breweries, etc.). Placement on hills, slopes, on the foregrounds of river valleys and river basins, also enhanced defensibility while providing suitable exposition to the city, ideatively elevating its status and rank, while also facilitating spatial orientation for travelers (Table 3). I found no direct link between terrain conditions and founding in only two cases (Byczyna, Strzelce Opolskie).

Table 3. Functions-water and terrain.

\begin{tabular}{ccc}
\hline Terrain & Defensibility & Hills, Slopes \\
\hline Waterways & Exposition & \\
\hline Transport & River routes, crossings \\
\hline Economy & $\begin{array}{c}\text { Commerce } \\
\text { Fishing } \\
\text { Others (e.g., mills) }\end{array}$ \\
\hline Defensibility & $\begin{array}{c}\text { River bed } \\
\text { Wetlands, floodlands }\end{array}$ \\
\hline Exposition & $\begin{array}{c}\text { Vista foregrounds of river } \\
\text { valleys and wetlands }\end{array}$ \\
\hline
\end{tabular}

\subsection{Historical Heritage of Towns-Urban Layout, Architecture, Skylines}

The environmental determinants discussed above, together with the formal and legal conditions of town charters [56,80], affected the spatial form of towns. Their key features include an oval plan with a geometric street grid filled with blocks of buildings, a centrallyplaced square, and masonry city fortifications with a system of gates and towers. The quality of such a layout's composition was determined by the proportions of each part, visual linkages, legible compositional axes, and skylines. The application of metrological methods of measuring parcellation modules began already in the 1950s, and is continued today $[55,81]$.

The towns under study, in comparisons to the period's significant urban centres throughout Silesia, for example, Wrocław, can be considered small and very small. Their town charters were issued mainly in the thirteenth century. The area inside the city walls was between 8.7 ha, as in Krapkowice, to 18.6 ha in Namysłów. They possessed all of the previously mentioned features of Silesian towns, yet their planning was not as thorough, and often applied only to the blocks adjacent to the market square. Their major compositional axes were often the result of the course of a trade route (e.g., Krapkowice).

Market squares were typically placed in the centre of a layout-at the crossing of trade routes, yet there were instances where this rule was not followed, i.e., in Głogówek (due to the location of the castle). Their size ranged from 0.6 ha (Byczyna) to 1.4 ha (Paczków), and their central spaces were occupied by a so-called market block that consists of the town hall or town hall and adjacent townhouses [28]. These complexes had a representative and commercial function. Their main element-the tower, was the dominant of the urban interior and an important element of the city panorama. Also, churches were 
important elements in compositional terms, with visual linkages with the Market Square (Głubczyce being an exception). Due to functional reasons and a town's size, it was often placed adjacent to the walls, and often had a docking defensive wall (Krapkowice, Strzelce Opolskie). Any castles and nearby structures were undeniably important elements, which could: be located inside an urban structure (Głogówek), be adjacent to it (Otmuchów) or be a separate element (Opole). The essential characteristics of the towns under study have been presented in Table 4 .

Table 4. General characteristic of Silesian towns (own study based on $[28,30,56,77,80]$ ).

\begin{tabular}{cc}
\hline Town charter issuance & $\begin{array}{c}\text { Biała 1225, Byczyna 1268, Głogówek 1275, Głubczyce } \\
\text { przed 1253, Głuchołazy 1225, Grodków 1278, Kluczbork } \\
\text { 1253, Krapkowice 1284, Opole 1217, Namysłów via 1270, } \\
\text { Otmuchów via 1347, Paczków via 1254, Prudnik 1279, } \\
\text { Strzelce Op., 1290, Ujazd 1223 }\end{array}$ \\
\hline Plan & $\begin{array}{c}\text { Oval plan (boat/pseudo-oval shape, 'dwarf city'), } \\
\text { enclosed, grid-based, rectangular layout, with a } \\
\text { geometricised main square (Ring, Circus) in the centre, } \\
\text { surrounded by fortifications on an oval-like plan. } \\
\text { Layouts both regular and distorted by local conditions }\end{array}$ \\
\hline Major composition elements & Module, axis -> market square, parcel, streets \\
\hline Functional buildings & $\begin{array}{c}\text { Fortifications, town hall, church, monastery, hospital, } \\
\text { castle, others (synagogues) }\end{array}$ \\
\hline Fortifications & $\begin{array}{c}\text { Moats, embankments, walls-made of stone (curtain } \\
\text { wall), 1.5-2.5 m thick, height without breastwork at } \\
4.5-8.4 \text { m), towers, gates. }\end{array}$ \\
\hline Main identification (skyline) elements & City walls, towers, church, castle \\
\hline
\end{tabular}

The shape of the town was also adapted to local environmental conditions, which is why they differed from a perfect oval, taking on more organic forms, as in the cases of Głogówek, Głubczyce, Otmuchów, Krapkowice. The most regular layouts were found in Paczków, Grodków, Głuchołazy, and Byczyna.

Economic determinants contributed to the development of many of these towns remaining wooden up to as late as the nineteenth century (except for town halls, churches, residential buildings, and town walls). This often led to extensive fires, both due to external and internal causes (e.g., Hussite raids in the fifteenth century). The current urban structure largely corresponded to the one from the period of the towns' respective charters.

City walls were erected in later periods than the towns themselves, namely in the fourteenth, fifteenth, and even the sixteenth century. They were built mostly from stone or brick. At present, the reconstruction of their appearance is highly problematic due to their fragmentary preservation. Their height varied. In Krapkowice, it reached $5.4 \mathrm{~m}$ up to the wall walk, while in Paczków, the entire wall was $9 \mathrm{~m}$ high. Their thickness also varied, from $0.9 \mathrm{~m}$ in Biała to $2.5 \mathrm{~m}$ in Paczków. Towers and gates were additional elements. The natural terrain was of great significance in the fortification structure, and was put to use to great effect. Wherever the terrain was not difficult enough, additional embankments and moats were placed.

The images of towns in Wernher's historical iconography [71,72], and those of others, proved to be a great source of information on the appearance, construction principles, and forms of individual structures, as well as period landscapes. The distinguishing features of old skylines included a wide vista foreground, horizontal greenery, water or field and fortification layouts, as well as landmarks and minor landmarks in the form of town halls, churches, and castles. Gates, city towers, and chapels acted as accents (Figure 1). 


\subsection{Contemporary Towns and Cities-Development Directions}

Comparing historical maps with the numerical terrain model and maps of areas in danger of flooding for the towns under study showed that the development model defined in the Middle Ages, limited by the terrain, the course of waterways and swamplands, had been maintained until the nineteenth century. The more difficult the conditions, the slower the development, with a stronger utilisation of pre-urbanised areas. Such specimens possessed the best-preserved spatial layouts and followed a continuity-based development model (Biała, Byczyna, Krapkowice, Otmuchów).

Of course, a beneficial economic situation, especially the development of industry in the nineteenth century, accelerated the region's dynamic transformation. Especially those localities that were given access to the railroad and had the necessary resources quickly began turning into chaotically planned layouts with a mixed functional structure (Opole, Prudnik, Głubczyce, Głuchołazy).

What is important, the environmental factors that had constrained development in the past, can currently be said to define the high environmental and landscape potential of the towns under study.

The town of Krapkowice is an example of this, as it is located on a high escarpment above the Oder River. Swamplands, visible on an archival map, occupy the same area as indicated on a contemporary range of areas in danger of flooding and thus excluded from development. This made it possible to create extensive recreational areas in the present. Furthermore, interesting visual linkages between two neighbouring medieval towns, Krapkowice and Otmęt, were preserved (at present they constitute one city). This is one of the more interesting cases of a surviving historical cultural landscape of a river valley, further enhanced by the layer formed by industrial buildings from the nineteenth and twentieth centuries (which are listed heritage sites) (Figure 3).
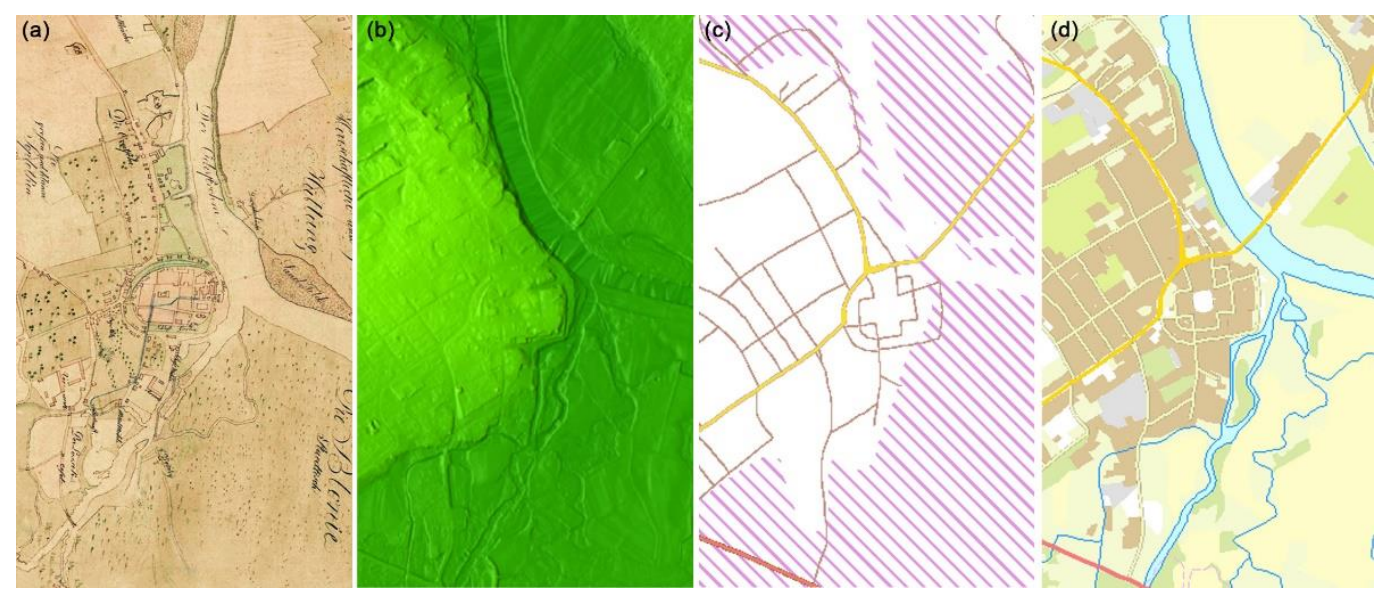

Figure 3. Case study-Krapkowice (Krappitz), (a) Town map from 1811 (Archiwum Państwowe w Opolu), (b) Numerical Terrain Model, (c) Areas in danger of flooding, (d) Contemporary development (own study based on OWI-OGIS Portal data).

In tourism geography studies, it is assumed that varied terrain enhances a given area's attractiveness to tourists $[65,66]$. In the context of this study, this provides additional advantages: (1) It enhances landscape attractiveness via distant visual linkages, interesting panoramas, and exposing heritage sites, (2) Surviving land reserves located mostly along river valleys (e.g., the Oder, the Osobłoga, the Nysa Kłodzka) are areas that are intriguing in terms of wildlife, (3) An urban form that has survived in a shape close to its historical version is an undeniable asset in urban heritage terms, (4) Surviving land reserves can currently be used to create recreational areas.

One example of this is the conversion of areas in danger of flooding or that were previously water reservoirs into allotment gardens (Prudnik), sports grounds (Grodków) 
or urban parks (e.g., Kluczbork) or keeping them as semi-natural areas of environmental value (e.g., Otmuchów).

The contemporary directions of development for each town should be devised based on the town's specific character and local conditions. Nevertheless, according to the studies above, the priority tasks should be: to increase the present housing density while adjusting to the height of the existing buildings, draw up landscape view protection zones for the landmark historic urban layouts, and mark natural environment protection zones to secure the preserved natural and semi-natural areas. New institutions should be located as remotely from the historical center as possible. They shall require a landscape view analysis as not to distort the town's historic silhouette. Their composition should be incorporated with the existing layout. Several cities shall require a reorganization of the wheel transportation system so that it by-passes the historic center.

\subsection{Contemporary Town and Cities-State of Preservation of Urban Layouts, Fortifications, and Skylines}

The value of the spatial layouts of the towns and cities under study, understood as the sum of the artistic, compositional, and historical value and their state of preservation, resulted in all of them being entered in the immovable monuments register of the Opole Voivodeship. However, the original urban layouts of many of them are blurred or deformed. This was caused by the Second World War and Polish post-war conservation theory.

Comparative analyses of historical von Wrede's plans and contemporary maps showed that all towns have a well-preserved urban layout. The surviving street network in all towns means that compositional axes and visual linkages can still be identified. Market squares, still surrounded by compact development, continue to play their formal functions. Even in the most transformed ones (Głubczyce, Otmuchów, and Strzelce Opolskie), these elements are still visible. Biała, Byczyna, Głogówek, Głuchołazy, Krapkowice, and Paczków have the best preserved town layout.

The market square, surrounded by densely developed buildings, still fulfils its representative functions. Town halls formed their main elements in 12 towns (the exceptions being Krapkowice, Ujazd, and Głuchołazy). They date back to the origins of the Middle Ages, but their forms show the difficult history of the region. They have gothic fragments (Opole), largely combining elements of Gothic and Renaissance (Namysłów), Renaissance (Głogówek), Renaissance and Baroque (Otmuchów), several from the 19th century (e.g., Grodków, Strzelce Opolskie). Despite a historicising form, the building in Głubczyce is from the twenty-first century.

As a result of wartime operations, the development of old-town complexes suffered varying degrees of damage. The towns that suffered the most included Nysa, Brzeg, Głogówek, Głubczyce, and Opole, which lost over half of their old-town buildings [38]. The spatial layout of Głubczyce was entered in the register immediately after the war (in $1949)$, but the development of its central area (100\% of its fabric) in the form of multi-family housing blocks, that completely altered the character of its space, is from the 1960s.

Buildings of this type are in all market-side frontages of the towns under study, with the exception of Gluchołazy and Opole. These buildings formed between 20 and $100 \%$ of a given frontage's development. The majority of tenement houses have elevations shaped at the turn of the 19th and 20th centuries (e.g., Krapkowice), and in some cities also-Baroque (Głogówek, Namysłów).

The main religious buildings of medieval origin, remodelled and extended to varying degrees, have survived into the present. Even residential buildings continue to be major spatial elements, although their technical condition varies. In Prudnik and Opole, only a single tower has survived, while in Ujazd or Strzelce Opolskie, the buildings were found to be in a state of permanent ruin, while in other towns, they were used as museums (Namysłów), hotels (Otmuchów), or schools (Krapkowice).

The problem of the remains of town walls and their exhibition has, since the nineteenth century, been a conservation problem, which, depending on the local situation, was solved in different ways. In terms of conservation theory, reconstruction often saw use in the 
nineteenth century, while after the Second World War, there was a shift towards the concept of the permanent ruin [37]. The post-war situation in Lower Silesia meant that the remains of town walls were not sufficiently recognised and saw their gradual removal. A series of research and conservation projects that were mostly intended to secure them was performed as late as towards the end of the 1960s [37]. Contemporary revitalisation programmes (e.g., Brzeg, Paczków) approached their respective subjects in a much more comprehensive manner.

The state of preservation and conservation of fortifications proved to be highly differentiated (Table 5). Out of 15 towns, only 2 were found to have retained almost a complete ring of defensive walls with gates and towers (Paczków and Byczyna). Eight featured significant elements of the walls and singular towers and gates $(22-56 \%)$, while in four cases, these were fragments at a level of 1-13\% of circumference (or structures like towers and gatehouses, as in Gluchołazy and Prudnik). Kluczbork had a wooden and earthen rampart from the north [34]. Only Ujazd had no surviving wall fragments visible above grade. Of note is the fact that all surviving wall fragments, as well as the walls and towers, were either listed in the immovable monuments register individually or as a whole (the entire system).

Table 5. City walls—state of preservation (own study [30,31,34,35]).

\begin{tabular}{|c|c|c|c|c|c|c|c|c|}
\hline & & $\begin{array}{l}\text { Period of } \\
\text { Construction, } \\
\text { Century }\end{array}$ & $\begin{array}{l}\text { Approximate } \\
\text { Wall } \\
\text { Circumference }\end{array}$ & $\begin{array}{c}\text { Surviving } \\
\text { Sections } \\
{[\%]}\end{array}$ & Gatehaus & Tower & Turret & Listed Site \\
\hline 1 & Biała & Fifteenth & 1100 & M & - & 1 & yes & yes \\
\hline 2 & Byczyna & Fifteenth-sixteenth & 1000 & $\mathrm{~L}$ & 3 & 1 & yes & yes \\
\hline 3 & Głogówek & Fourteenth-fifteenth & 1350 & $M$ & 1 & 1 & yes & yes \\
\hline 4 & Głubczyce & $\begin{array}{l}\text { Thirteenth, } \\
\text { fourteenth-fifteenth }\end{array}$ & 1500 & M & - & - & yes & yes \\
\hline 5 & Głuchołazy & Fourteenth, fifteenth & 970 & S & - & 1 & - & $\begin{array}{l}\text { only a } \\
\text { tower }\end{array}$ \\
\hline 6 & Grodków & $\begin{array}{l}\text { Fourteenth, } \\
\text { sixteenth }\end{array}$ & 1270 & M & 2 & 1 & yes & yes \\
\hline 7 & Kluczbork & Fifteenth-sixteenth & $850(1290)$ & M & - & 1 & - & yes \\
\hline 8 & Krapkowice & Fourteenth & 850 & $M$ & 1 & - & yes & yes \\
\hline 9 & Namysłów & Fourteenth & 1600 & M & 1 & 2 & yes & yes \\
\hline 10 & Opole & Fourteenth & 1500 & $S$ & - & 1 & yes & yes \\
\hline 11 & Otmuchów & Fourteenth & 1200 & $S$ & - & 1 & no & yes \\
\hline 12 & Paczków & Fourteenth & 1200 & $\mathrm{~L}$ & 1 & 3 & yes & yes \\
\hline 13 & Prudnik & Fourteenth & 1100 & $S$ & - & 1 & yes & yes \\
\hline 14 & $\begin{array}{l}\text { Strzelce } \\
\text { Opol. }\end{array}$ & Fourteenth & 900 & $S$ & - & 1 & yes & yes \\
\hline 15 & Ujazd & Fourteenth & 1100 & $\mathrm{~N}$ & - & - & - & - \\
\hline
\end{tabular}

Surviving section in \%: 1-large part, $\mathrm{m}$-medium, s-small, $\mathrm{n}-$ none.

In the context of the problem under study, it is not the masonry structures themselves that are significant, but their accompanying areas-sites that remained in places formerly occupied by demolished walls (that could still contain underground remains), moats, or embankments. Due to the shape of the towns, they form ring-like belts. In the nineteenth century, following European tendencies, they were converted into areas of landscaped public greenery (Byczyna). However, the densification of central development turned them into attractive sites for construction [37]. This is why they were used for public 
and private buildings—single-family (e.g., Grodków, Figure 4) as well as transport routes (Kluczbork) and car parks (Głogówek, Prudnik). The shape of the terrain and the nonuniform soil structure in the area made them into modern-day wastelands or overgrown gardens (Biała, Krapkowice).
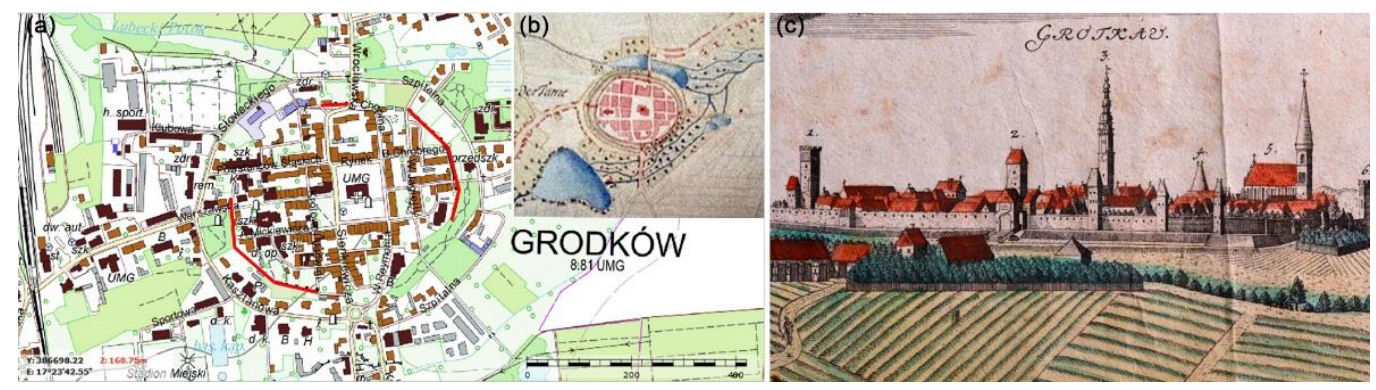

Figure 4. Case study-Grodków (Grotkau), (a) Topographic map (red line-surviving sections), (b) City plan from ca. 1750 (C.F. von Wrede [28]), (c) View of the city from the north (ca. middle eighteenth century, W.B. Wernher (source: https: //medievalheritage.eu/en/main-page/heritage/poland/grodkow-city-defensive-walls/, accessed on 15 October 2020).

During my research, I identified the following major problems in areas of historical fortifications:

- $\quad$ a varied state of ownership;

- a varied state of preservation;

- a varied state of development;

- fragmentation, gaps in the defensive perimeter;

- lack of archaeological studies;

- landscaped accompanying greenery, in the form of typical city gardens and parks of low visual and functional quality;

- decisions to establish a green area not backed by a functional need in adjacent areas, made randomly and only to follow a general tendency;

- $\quad$ tall trees obscured walls (landscaped greenery);

- natural succession, which caused walls to be obscured from further observation points, erasure of skylines;

- low attractiveness and quality of nearby buildings—an element ignored in conservation and restoration (Figure 5).
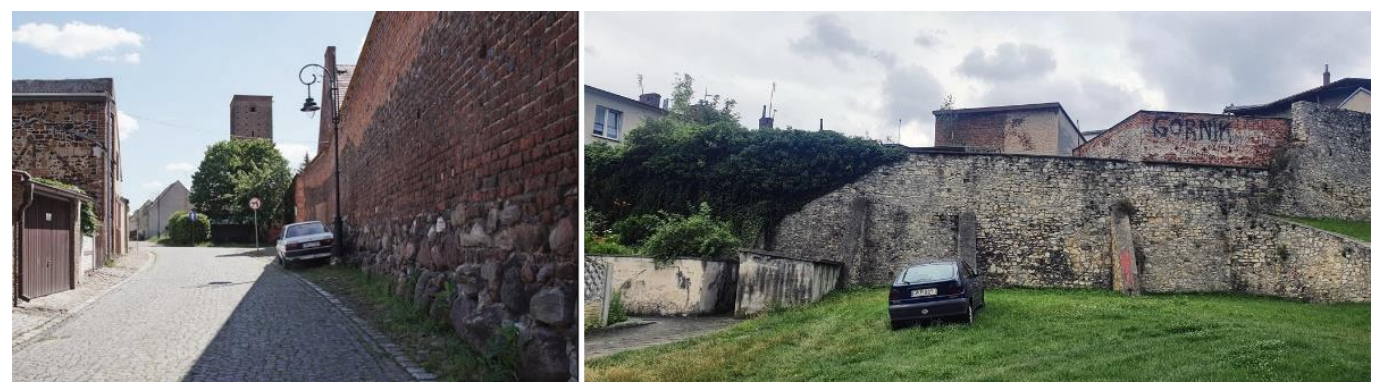

Figure 5. City walls-Byczyna and Krapkowice.

The remains of medieval fortifications are an essential element of history and the present-day identification of the towns under study. This is why it is necessary to give them proper exposition-both regional and local, and the forgotten and unutilised exposition from water-level. It is an undeniable visual attractor that provides an opportunity to recreate medieval landscapes with visible important landmarks such as castles, churches, or fortification fragments. It is important to prevent the consequences of natural succession.

The degree of preservation of city walls gives them poor potential in individual terms, yet in connection with restoration and other elements, including accompanying greenery 
and an urban greenery system, it can result in an opportunity to enhance the attractiveness of these elements both visually and functionally. Attention should therefore be paid to their educational value and promotion, including as a system of linked cities. On the scale of a single town, we should merge the remaining fragments and connect them with tourist trails and other medieval structures. We should likewise provide correct exposition and accessibility, as creating a system of urban greenery based on fortified areas can bring benefits not only in the field of conservation, but also to society and ecology.

Skyline legibility analyses as observed from main road approaches allowed us to identify four towns with the highest skyline compositional value. These were towns that displayed the best state of preservation in terms of exposition, development directions, and legible functional historical structures-which acted as landscape landmarks and sublandmarks. Despite an altered architectural fabric, primarily in terms of form and character of the cover of housing, key layout elements remained legible, and skylines retained their historical character (Biała, Głogówek, Otmychów, Paczków). In the case of Byczyna-poor exposition resulted from its terrain-related, site-specific conditions-it stands on a small hill—and partially from the presence of buffer strips and accompanying access roads.

\subsection{Greenery in the Towns}

Statistical data procured from the GUS included the following categories: rest and walking parks, urban gardens, street greenery, housing estate greenery, cemeteries, and municipal forests (Table 6).

Table 6. Landscaped greenery, data from the GUS (as given in 2020, accessed on 30 January 2021).

\begin{tabular}{|c|c|c|c|c|c|c|c|c|}
\hline & $\begin{array}{c}\text { Municipal } \\
\text { Unit }\end{array}$ & $\begin{array}{c}\text { Rest and } \\
\text { Walking } \\
\text { Parks } \\
\text { [ha] }\end{array}$ & $\begin{array}{c}\text { Urban } \\
\text { Gardens } \\
\text { [ha] }\end{array}$ & $\begin{array}{c}\text { Street } \\
\text { Greenery } \\
\text { [ha] }\end{array}$ & $\begin{array}{l}\text { Housing } \\
\text { Estate } \\
\text { Greenery } \\
\text { [ha] }\end{array}$ & $\begin{array}{c}\text { Cemeteries } \\
\text { [ha] }\end{array}$ & $\begin{array}{c}\text { Municipal } \\
\text { Forests } \\
\text { [ha] }\end{array}$ & $\begin{array}{l}\text { Total } \\
\text { [ha] }\end{array}$ \\
\hline 1 & Biała & 0.0 & 1.4 & 1.0 & 1.4 & 1.1 & 0.0 & 4.9 \\
\hline 2 & Byczyna & 6.3 & 7.3 & 0.0 & 19.0 & 1.9 & 0.0 & 34.5 \\
\hline 3 & Głogówek & 16.8 & 0.7 & 0.7 & 19.2 & 2.4 & 12.1 & 51.9 \\
\hline 4 & Głubczyce & 11.3 & 7.2 & 6.8 & 31.3 & 5.6 & 0.0 & 62.2 \\
\hline 5 & Głuchołazy & 0.0 & 4.3 & 0.5 & 20.3 & 8.6 & 178.6 & 212.3 \\
\hline 6 & Grodków & 6.4 & 4.6 & 0.0 & 15.9 & 1.9 & 0.0 & 28.8 \\
\hline 7 & Kluczbork & 70.0 & 4.6 & 4.7 & 107.2 & 7.2 & 128.6 & 322.3 \\
\hline 8 & Krapkowice & 52.6 & 6.3 & 6.5 & 71.8 & 3.0 & 1.6 & 141.8 \\
\hline 9 & Namysłów & 29.2 & 17.2 & 7.7 & 76.1 & 10.3 & 4.8 & 145.3 \\
\hline 10 & Opole & 182.5 & 5.0 & 216.0 & 368.4 & 44.7 & 13.9 & 830.5 \\
\hline 11 & Otmuchów & 0.0 & 8.5 & 0.3 & 8.5 & 3.0 & 109.6 & 129.9 \\
\hline 12 & Paczków & 18.2 & 2.5 & 1.0 & 23.7 & 2.9 & 4.2 & 52.5 \\
\hline 13 & Prudnik & 11.5 & 15.2 & 4.5 & 43.5 & 7.5 & 7.9 & 90.1 \\
\hline 14 & $\begin{array}{l}\text { Strzelce } \\
\text { Opolskie }\end{array}$ & 64.6 & 18.0 & 3.3 & 104.3 & 7.6 & 2.3 & 200.1 \\
\hline 15 & Ujazd & 5.4 & 0.2 & 0.2 & 5.8 & 1.5 & 0.0 & 13.1 \\
\hline
\end{tabular}

According to statistical data, Biała, Ujazd, and Strzelce Opolskie had the least amount of greenery $(0.3,0.4$, and $0.8 \%$ of their respective areas), while Głuchołazy and Kluczbork had the highest amount of greenery (31 and 26\%, respectively). The average percentage of land covered by greenery in all towns was $7.7 \%$, with a national average of $34.4 \%$. This clearly points to such land having a very small share in the type of towns under study. 
The data presented above concerns public greenery, with a broad range of area types ignored: single-family housing estates, greenery in religious complexes and special-purpose greenery-forming parts of schools, hospitals, sports areas, etc., in addition to allotment gardens, which are considered productive greenery. I could not find statistical data for environmentally valuable greenery in the central areas of the towns under study. I also observed that castle parks (Ujazd or Otmuchów) were not included in the statistics.

After an analysis of existing landscaped greenery, the fact that the towns analysed are small and located in urban-rural municipalities appeared worth noting. According to data provided by the GUS for 2019 , urbanised areas amounted to only $6.2 \%$ of the Opole Voivodeship. The remaining land was used for agricultural or is semi-natural (forests, river valleys, wetlands). As such, the demand for city or estate parks is low, and landscaped greenery had a more formal function-in the form of ornamental city or front gardens.

Thus, assessment of urban greenery potential for shaping systems of greenery accounted for the diversity of present forms, semi-natural areas accompanying waterways in the immediate vicinity of central zones and preserved post-fortress areas (landscaped and non-landscaped, accompanying fully and partially preserved wall fragments) (Table 7).

Table 7. Landscaped greenery.

\begin{tabular}{|c|c|c|c|c|c|c|c|c|c|c|c|}
\hline & Municipal Unit & $\mathbf{R v}$ & $\mathrm{Cp}$ & $\mathrm{Sq}$ & $\mathrm{Cm}$ & Al & Pfg & Wl & $\mathrm{He}$ & Ot & Total \\
\hline 1 & Biała & $x$ & $x$ & $\mathrm{x}$ & $x$ & $\mathrm{x}$ & $x$ & $x$ & $x$ & $x$ & 9 \\
\hline 2 & Byczyna & $x$ & $x$ & $x$ & $x$ & $x$ & $x$ & $x$ & $x$ & $x$ & 9 \\
\hline 3 & Głogówek & $x$ & $x$ & & $x$ & $\mathrm{x}$ & & $x$ & $x$ & & 6 \\
\hline 4 & Głubczyce & $x$ & $x$ & $x$ & $x$ & $\mathrm{x}$ & $x$ & $x$ & $x$ & $x$ & 9 \\
\hline 5 & Głuchołazy & $x$ & $x$ & $x$ & $x$ & $\mathrm{x}$ & & & $x$ & $x$ & 7 \\
\hline 6 & Grodków & $x$ & Pfg & $\mathrm{x}$ & $x$ & $\mathrm{x}$ & $x$ & $x$ & $\mathrm{x}$ & & 7 \\
\hline 7 & Kluczbork & $x$ & $x$ & & $x$ & $\mathrm{x}$ & $x$ & $x$ & $x$ & & 7 \\
\hline 8 & Krapkowice & $x$ & $x$ & $x$ & $x$ & $x$ & $x$ & $x$ & $x$ & $x$ & 9 \\
\hline 9 & Namysłów & $x$ & $\mathrm{x}$ & $x$ & $x$ & $\mathrm{x}$ & $x$ & $x$ & $\mathrm{x}$ & & 8 \\
\hline 10 & Opole & $x$ & & $x$ & $x$ & $x$ & & & $x$ & & 5 \\
\hline 11 & Otmuchów & $x$ & $x$ & & $x$ & $x$ & & $x$ & $x$ & $x$ & 7 \\
\hline 12 & Paczków & $x$ & Pfg & & $x$ & $\mathrm{x}$ & $x$ & $x$ & $x$ & $x$ & 7 \\
\hline 13 & Prudnik & $x$ & $x$ & & $x$ & $x$ & & & $x$ & $x$ & 6 \\
\hline 14 & Strzelce Opolskie & $x$ & $x$ & & $x$ & $\mathrm{x}$ & & & $\mathrm{x}$ & $x$ & 6 \\
\hline 15 & Ujazd & $x$ & $x$ & & $x$ & $x$ & & & $x$ & $x$ & 6 \\
\hline
\end{tabular}

Rv-river valley and wetland greenery, $\mathrm{Cp}$-city parks, Sq-green squares inside the city walls, $\mathrm{Cm}$-cemeteries, Al一allotment gardens, Pfg—Post-fortification greenery, Wl—waste lands next to city walls, He-housing estate greenery, Ot—other (in Table 8: 9-7 = 2p, 6-4 = 1p, 3-1 $=0 \mathrm{p})$. 
Table 8. Cultural landscape potential.

\begin{tabular}{|c|c|c|c|c|c|c|c|c|}
\hline & & $\begin{array}{l}\text { Environmental } \\
\text { Diversity } \\
\text { of a Site }\end{array}$ & $\begin{array}{l}\text { Urban } \\
\text { Layout } \\
\text { Legibility }\end{array}$ & $\begin{array}{l}\text { Retained De- } \\
\text { velopment } \\
\text { Trajectories }\end{array}$ & $\begin{array}{l}\text { Surviving } \\
\text { City Fortifi- } \\
\text { cations }\end{array}$ & $\begin{array}{l}\text { Legibility } \\
\text { of Skyline } \\
\text { Composi- } \\
\text { tion }\end{array}$ & $\begin{array}{l}\text { Landscaped } \\
\text { Greenery }\end{array}$ & $\begin{array}{c}\text { Individual } \\
\text { Qualities and } \\
\text { Cultural } \\
\text { Landscape } \\
\text { Potential } \\
\end{array}$ \\
\hline 1 & Biała & 2 & 2 & 2 & 1 & 2 & 2 & 11 \\
\hline 2 & Byczyna & 0 & 2 & 2 & 2 & 1 & 2 & 9 \\
\hline 3 & Głogówek & 1 & 2 & $\begin{array}{c}\text { 1, except for } \\
\text { the east }\end{array}$ & 1 & 2 & 1 & 8 \\
\hline 4 & Głubczyce & 1 & 1 & 0 & 1 & 1 & 2 & 6 \\
\hline 5 & Głuchołazy & 1 & 2 & 0 & 0 & 0 & 2 & 5 \\
\hline 6 & Grodków & 1 & 1 & 2 & 1 & 1 & 2 & 8 \\
\hline 7 & Kluczbork & 1 & 1 & 1 & 1 & 0 & 2 & 6 \\
\hline 8 & Krapkowice & 2 & 2 & 2 & 1 & 1 & 2 & 10 \\
\hline 9 & Namysłów & 1 & 1 & 1 & 1 & 1 & 2 & 7 \\
\hline 10 & Opole & 1 & 1 & 0 & 0 & 1 & 1 & 4 \\
\hline 11 & Otmuchów & 2 & 1 & 2 & 1 & 2 & 2 & 10 \\
\hline 12 & Paczków & 1 & 2 & 1 & 2 & 2 & 2 & 10 \\
\hline 13 & Prudnik & 1 & 1 & 0 & 0 & 1 & 1 & 4 \\
\hline 14 & $\begin{array}{l}\text { Strzelce } \\
\text { Opol. }\end{array}$ & 0 & 1 & 1 & 0 & 1 & 1 & 4 \\
\hline 15 & Ujazd & 1 & 1 & 1 & 0 & 1 & 1 & 5 \\
\hline
\end{tabular}

In the first group, I examined all towns and identified: cemeteries, housing estate greenery, allotment gardens and, in most cases, city parks. River valley and wetland greenery was also found to be present in all towns.

Post-fortification areas were converted into landscaped greenery in eight towns (e.g., Paczków, Krapkowice). In two cases, even the role of the main city parks was taken over by Planty (Post-fortification greenery). It should be noted that only one case featured a complete fortification ring (Paczków), while in others, the fragments that were not developed became wastelands, wild gardens, and car parks. A possibility of their partial restoration was determined in nine cases. Historical greenery included mainly cemeteries and parks. Insofar as cemeteries had a stable form and function, the parks formed a diverse group. They originated from residential parks-palatial and castle parks (Głogówek, Strzelce Opolskie), and were founded in areas of former city ponds (Głubczyce, Byczyna, Kluczbork) or areas in danger of flooding (Głogówek). Numerous small squares were also found (Byczyna, Biała, Krapkowice), and typically accompanied transport and circulation or filled in gaps in the urban fabric. All cities have riverside greenery and large areas of allotment gardens.

In Opole Voivodeship's towns varied terrain and a diversity of existing plants, both in terms of form, genesis, function, state of development, and environmental and cultural assets, offers many possibilities for creating greenery systems. The greater this diversity, the more advanced can a system become, which is conducive to biodiversity and ecological stability. In combination with improving visual attractiveness and cultural identity, it can become a basis for creating sustainable cities $[7,82,83]$. The concepts of green infrastructure or even urban ecological networks can also be applied here $[84,85]$.

They can be based on existing landscaped greenery fragments-preserved areas formerly occupied by fortifications, parks and gardens, suburban forests and areas with high environmental potential—along rivers, wetlands, buffer greenery, municipal forests. 
Other forms will also play an important role here—partially accessible greenery—allotment gardens, cemeteries, monastery and residential gardens, as well as home gardens.

A high potential for urban greenery systems was detected in 8 out of the 15 cases under study. It was fully ruled out in only two cases due to highly dense development structures.

Accounting for the rating indicators of the towns under study, it can be observed that the systems would become a combination of ring (post-fortress area greenery), wedge (parks, promenades, street greenery), and linear (riverside greenery) systems. American riverside parkways [6] appear to be a proper reference point, yet on a slightly different scale. This is facilitated by the region's complex hydrographic system and existing regional and local ecological corridors outlined along the Oder and Osobłoga rivers.

\subsection{Cultural Landscape Potential}

As above, the following indicators were of key significance to the contemporary state of cultural and environmental heritage: site-specific environmental determinants, urban layout, urban morphology, city fortifications, skylines, and greenery. Their assessment allowed us to identify cities with the greatest landscape potential (Table 8).

The towns with the highest scores were those which managed to preserve their historical landscape on the highest level. These included: Biała, Byczyna, Krapkowice, Otmuchów, and Paczków. The towns with the lowest evaluation of the studied natural and cultural potential were: Głucholazy, Opole, Prudnik, Strzelec, and Ujazd.

\section{Discussion}

At present, the Opole Voivodeship features numerous cases of architecture and urban layouts from the period of the region's most dynamic development- the fourteenth and nineteenth centuries. They include the previously mentioned urban layouts of medieval towns. As observed by Eysymontt in relation to the area known since the sixteenth century as Lower Silesia, these towns did not make significant contributions to the development of western urbanization, and were of little value in terms of innovation [56]. This is a perspective from arts history studies and is essentially accurate, if not detrimental in the context of public awareness as to the attractiveness of such structures in the public conscious. However, this does not detract from the values that they possess and which have been detected, nor from their regional significance. In terms of other Silesian towns, their medieval urban planning structure and its key elements may be considered as wellpreserved. However, while the city layout itself is clear, the post-war housing tissue that filled specific city blocks in such places as Strzelce Opolskie or Głubczyce has contributed to the loss of the historic landscape of the city center.

I compared environmental, urban, architectural, and landscape factors that were and continue to be significant to the shape of these towns. What is notable, contemporary GIS tools and source materials made them relatively simple to analyze (historical maps, GIS, field studies).

Several problems concerning data and the possibility of its distortion were noted during the course of this study. The first and very basic involved obtaining the archival city plans. In order to conduct a comparative analysis of a large group of towns with similar origins, it was crucial to secure the plans which originated in the same period or had the same author. This allowed them to make proper evaluation of the state of preservation of urban layouts during a similar time period or eliminate errors made within some markings on those plans. In this particular research study, the city plans used as basic were those by Christian Friedrich von Wrede. The studies with the least possible error factor in evaluating the original conditions were the studies conducted using the numeric maps of terrain and topographic maps. Interlaying the archival plans with the contemporary ones, it is easier to analyze and compare the development directions of the respective areas.

While granting points in the evaluation, there is always a possibility of a subjective evaluation, which results from the researcher's experience and his or her body of knowl- 
edge. For instance, when studying the level of preservation of the urban tissue, what can become a key element of evaluation are the quality and percentage of the housing tissue or that of the preserved market block. What was important in conducting this study was the preserved layout of the original city blocks and its key elements (e.g., town hall, castle, church, fortifications). On the other hand, when studying the panoramic views, it is crucial to analyze the sightseeing points and identify such ones that would showcase both the historic panoramas as well as the panoramic views, which would be successful in exposing the best contemporary views. Statistical data turned out to be unhelpful in studying greenery. What constitutes an additional element of the evaluation in this case may be the size of the area, not only its diversity.

All towns received positive evaluations in terms of the preservation urban layout legibility and green areas. They scored averagely with regard to environmental diversity of a site, retained development trajectories, and quality of the panoramas. The lowest evaluation was given to the visibility of the remains of city walls. It has to be noted though that the lowest scoring towns in fact feature strongly developed urban planning systems. On the other hand, the highest scoring towns are of similar size (with the exception of Krapkowice). They also feature city walls preserved at high or average level and are attractively located (with the exception of Byczyna) which-considering their rather not intensively developed urban housing tissue-results in quite clear panoramas.

In the light of some changes, which have affected the factors analyzed in the study from the time the cities were established to the present day, these factors may be divided into three categories: durable, medium-durable, and volatile/variable. The first category includes natural environmental conditions whereas the second one comprises those related to architectural and urban state of development. The third category pertains to city greenery. Some of the irreversible processes, such as the post-war architectural solutions, reshaping, and the chaotic city expansion, may be partially eliminated through appropriately designed green infrastructure.

Environmental conditions are particularly important (the hydrographic network and terrain) as they had a considerable impact on the spatial form and functioning of cities and towns in the Middle Ages and over subsequent development periods. I did not observe direct correlations in this respect in only two cases. It is notable that the more difficult and complicated a given site's conditions were, the more difficult it was for spatial development to take place, which also resulted in a stable and sustainable urban development. At present, this was found to carry over to the survival of considerable reserves of natural green areas of high environmental potential. These large areas of healthy and functioning ecosystems with minimal intervention required are core areas of green infrastructure.

Meanwhile, Poland has been following one major tendency when it came to the maintenance of post-fortress areas. We could characterize them as conservative. In the projects undertaken towards the end of the nineteenth and the beginning of the twentieth century, the goal was to create representative and richly designed city parks or promenades (Kraków, Chemno, Brzeg, Paczków). The post-war approached concentrated primarily on works within the city walls themselves while greenery was an added but not necessary element. In order to continue the old tradition, cities built alleys or small parks (Prudnik) or squares (Krapkowice). Several municipalities opted for grass covered areas (Byczyna). This leads to an important question on the possibility to match proper exposition with a diverse attractiveness and aesthetics as well the functional aspects of these areas.

In turn, the latest experience in creating greenery systems based on the training of medieval and modern fortifications has, among others, Krakow, Poznan and Wrocław [86-88]. However, they are all large metropolitan cities, which makes their experience difficult to carry over to the Opole Voivodeship's small towns.

Despite a wide range of research on historical walls by ICOMOS Polska [39,40], I found no studies or guidelines concerning landscaped greenery that should be placed near such walls. Historical and climate conditions do not quite allow for applying vegetation solutions from abroad [89,90]. Accepted conservation doctrines concerning historical ruins, 
including the ruins of city walls, recommend keeping them in a state of so-called permanent ruin. It is assumed that that the best course of action is their conservation, proofing, and making them accessible to tourists [41]. In the case of ruins of significant buildings-such as castles-this is not difficult, but for more modest wall fragments, this can prove a considerable challenge. The Historical Ruins Preservation Charter, adopted by Resolution of the General Assembly of Members of PKN ICOMOS on 4 December 2012, states: 'the preservation of historical ruins should be comprehensive-it should cover surviving ruins, earthen forms (which are relics of historical fortifications), rubble layers and the landscape (of which the ruins are elements)' [91]. This is a rather enigmatic guideline, which, based on the principles of historical landscape design and the renovation of historical gardens, can provide a basis for proper action within the field of city walls.

However, it should be noted that Trochonowicz mentioned the following as being factors responsible for wall degradation: biotic factors caused by microorganisms, fungi, mould, and plants which appear spontaneously in such structures [92]. Scholars note that the ingrowing of the roots of trees that grow in the immediate vicinity of an area can cause mechanical damage. Shade cast on wall surfaces by tree canopies is conducive to damp build-up and the growth of algae and bryophytes [93]. Tall and old trees can also pose a threat during strong winds.

Comparative analyses performed during field studies in countries like Ireland, Italy (San Leone, Monteriggioni, Montalcino, Pisa), Croatia (Mototvun, Rovini, Pula), the Czech Republic (Spišský Hrad), along with the general conservation guidelines in this field, prepared as a part of the INTEREG Central Europe RUINS project [94,95], revealed two universal tendencies: preserving monuments in their most authentic form and exposing them in a landscape that is as close to historical as possible.

\section{Conclusions}

Cultural heritage plays a major role in the sustainable development of every region acting as a strengthening or even creative factor of the local identity. Studies showed that despite pejorative evaluation of the Opole region, there exists a large group of small-sized towns with promising landscape potential. Indicated values provide biodiversity and multiple ecosystem service benefit as a system of green infrastructure.

I demonstrated that site-specific determinants affected the contemporary assets of a place when studied from the perspective of the geography of tourism (tourism assets), the landscape (retention of historical skylines), and cultural heritage (a harmonious landscape). The place-based assets I isolated included:

- Environmentally valuable, diverse areas around towns;

- Retained development trajectories-as determinants of preserving the traditional landscape;

- Preserved and legible urban layouts;

- Entirely or partially preserved medieval city fortifications;

- Preserved historical skyline composition;

- Diverse landscaped and semi-natural greenery in the town's structure.

This set of features of medieval origin towns located in the Opole Voivodeship makes them an interesting complex of cultural heritage linked with environmental determinants. As for the towns and surviving remains of fortifications, it is necessary to create a system of urban greenery, and for the complex of cities-creating a system of towns with similar features. My study demonstrated that despite their regional character, they can define the identity and uniqueness of the area under analysis. Their potential should be utilized in new Voivodeship development strategies, including sustainable tourism. This is immensely significant due to the region's observable stagnation as well as economic and environmental problems.

Sustainability meant the balance between society and environment is, in this case, very important [96]. And the main elements on which it can be based in this region are the 
natural environment and cultural heritage. Green infrastructure networks should also be based on them, in which individual cities have great potential to create.

Sustainable development of the region should also focus on determining site-specific tourism potential, primarily the material, technical and economic infrastructure, and social assets of each site [66]. In the long term, this could facilitate the implementation of precepts of sustainable development in the area's economic activation, improving the state of its environment. Local communities should play a major role in this process as they will be main future beneficiaries of the achieved improvements [97,98].

Development of a green infrastructure network should begin with identification of environmental and cultural resources, which give the best idea of the character of the very place. In the cities embedded in their history, these resources shall be relatively easily identified, studied, and subjected to comparative analysis. It allows to emphasize the uniqueness of the network and because of it to increase its attractiveness, also in the context of its touristic appeal. As demonstrated in several examples, what remains crucial is the retaining by cities of their authenticity and historical character. Interestingly enough, in the case of the Opole Voivodeship, what contributed to preservation (in the studied cities) the elements carrying modern potential were natural and economic limitations. Another step which needs to be undertaken while creating a greenery system in the cities of medieval origins involves identification of the most important elements of the system's grid. Consideration should be given to the diversity of the existing areas (in terms of functions and ecosystems). It is important to combine the elements typical for historical cities (residential parks and cemeteries) with natural greenery (riverbeds, wetlands).

The most recognizable will be the historic center surrounded by the city wall remains and the accompanied greenery. The greenery of the linear character should be treated with a great deal of care because it is associated with specific architectural structures, archeological relics, and ecosystems.

With regard to the above, as well as the conducted studies, general guidelines were established for the purpose of designing the areas of medieval fortifications. These guidelines, which can also be applied in other cases, have been divided into three stages: investigation, design, and maintenance.

- Investigation: historical and urban research, visibility and exposition analyses, archaeological research, geological and soil morphology testing,

- Design: it should expose the monument, highlight its form, and enhance its values via a visual effect and new accompanying functions, new technical infrastructure in a form that does not compete with the monument. It is essential to adapt the site to persons from different age groups and persons with disabilities, while ensuring night-time use and exposition. Greenery should also mask technical elements and those of poor aesthetic quality; it can also restrict access while not visually interfering with the monument.

- Maintenance (as well as existing structures): maintenance and plant replacement programme, ongoing tree, bush and lawn maintenance, seasonal plant planting plan; reducing the effects of destruction by biotic entities, and the effects of natural succession.

Further research is necessary to formulate plant species selection guidelines for postfortification areas. These guidelines would depend on the character and size of the fortifications' remains, soil structure, and identifying areas for restoration and which should cover not only the historical remains themselves, but also accompanying areas. The principles above should also apply to areas already used as public greenery.

Funding: This research received no external funding.

Institutional Review Board Statement: Not applicable.

Informed Consent Statement: Not applicable. 
Data Availability Statement: Publicly available datasets were analyzed in this study. They are all shown in the 'References' section.

Conflicts of Interest: The authors declare no conflict of interest.

\section{References}

1. Raport o Stanie Zachowania Zabytków Nieruchomych w Polsce, Zabytki Wpisane do Rejestru Zabytków (Księgi Rejestru A i C); Narodowy Instytut Dziedzictwa: Warszawa, Poland, 2017. Available online: https://nid.pl/pl/Wydawnictwa/inne\%20 wydawnictwa/RAPORT\%200\%20STANIE\%20ZACHOWANIA\%20ZABYTK\%C3\%93W\%20NIERUCHOMYCH.pdf (accessed on 10 January 2021).

2. Szmygin, B. Teoria i kryteria wartościowania dziedzictwa jako podstawa jego ochrony. J. Herit. Conserv. 2015, 43, 44-52.

3. Szmygin, B. (Ed.) Wartościowanie Zabytków Architektury; Polski Komitet Narodowy ICOMOS, Muzeum Pałac w Wilanowie; Muzeum Pałac w Wilanowie: Warszawa, Poland, 2013.

4. Jarocka, A. (Ed.) Heritage Value Assessment Systems-The Problems and the Current State of Research; Lublin University of Technology; Polish National Committee of the International Council on Monuments and Sites ICOMOS: Lublin-Warsaw, Poland, 2015.

5. Hodor, K. Zieleń i ogrody w krajobrazach miast. Tech. Trans. Archit. 2012, 6, 7-15.

6. Zachariasz, A. Zieleń Jako Współczesny Czynnik Miastotwórczy ze Szczególnym Uwzzględnieniem Roli Parków Publicznych; Wydawnictwo Politechniki Krakowskiej: Kraków, Poland, 2006; Volume 103, pp. 28-29.

7. Ignatieva, M.; Stewart, G.H.; Meurk, C. Planning and design of ecological networks in urban areas. Landsc. Ecol. Eng. 2011, 7, 17-25. [CrossRef]

8. Rozmarynowska, K. Ogrody Odchodzace ... ? Z Dziejów Gdańskiej Zieleni Publicznej 1708-1945; Słowo/Obraz Terytoria: Gdańsk, Poland, 2011; pp. 94-97.

9. Forman, R.T.T. Some general principles of landscape and regional ecology. Landsc. Ecol. 1995, 10, 133-142. [CrossRef]

10. Cook, E.A. Landscape structure indices for assessing urban ecological networks. Landsc. Urban Plan. 2002, 58, 269-280. [CrossRef]

11. Ružička, M.; Mišovičová, R. The general and special principles in landscape ecology. Ekológia 2009, 28, 1-6. [CrossRef]

12. John, H.; Neubert, M.; Marrs, C. (Eds.) Green Infrastucture Handbook-Conceptual and Theoretical Background, Terms and Definition; Technische Universität Dresden: Dresden, Germany, 2019. Available online: https://www.interreg-central.eu/Content.Node/ MaGICLandscapes-Green-Infrastructure-Handbook.pdf (accessed on 5 January 2021).

13. Kieß, W. Urbanismus im Industriezeitalter. Von der Klassizistischen Stadt zur Garden City; Erst \& Son: Berlin, Germany, 1991; pp. 200-205.

14. Bińkowska, I. Natura i Miasto. Publiczna Zieleń Miejska we Wrocławiu od Schyłku XVIII do Poczatku XX Wieku; Muzeum Architektury, Wydawnictwo Via Nova: Wrocław, Poland, 2011.

15. Zachariasz, A. Zielony Kraków Dla Przyjemności I Pożytku Szanownej Publiczności; Wydawnictwo Politechniki Krakowskiej: Kraków, Poland, 2016.

16. Bogdanowski, J. Architektura Obronna w Krajobrazie Polski. Od Biskupina do Westerplatte; PWN: Warszawa, Poland, 1996.

17. Wielgus, K.; Środulska-Wilelgus, J.; Staniewska, A. Krajobraz Warowny Polski: Procesy Rewaloryzacji i Percepcji: Próba Syntezy; Wydawnictwo Politechniki Krakowskiej: Kraków, Poland, 2019.

18. Von Rohrscheidt, A.M. Wykorzystanie średniowiecznych obiektów obronnych w Polsce w ramach różnych form turystyki kulturowej. Tur. Kult. 2010, 6, 4-25.

19. Środulska-Wilelgus, J. Rola Turystyki Kulturowej w Ochronie i Udostępnieniu Krajobrazu Warownego; Wydawnictwo Politechniki Krakowskiej: Kraków, Poland, 2016.

20. Adamska, M.E. Zabytkowe planty miejskie w Brzegu. Przestrz. Urban. Archit. 2015, 1, 45-58. Available online: https: //www.ejournals.eu/PUA/2015/Volume-1/art/9542/ (accessed on 21 May 2021).

21. Adamska, W.E. The historic city parks of Opole Silesia. Tech. Trans. Archit. 2014, 5-A, 237-254.

22. Kimic, K. The location and role of old walls as green belts in shaping the landscape of towns in the 19th century. Tech. Trans. Archit. 2016, 1, 143-166. [CrossRef]

23. Hodor, K.; Fekete, A.; Matusik, A. The future of Planty Park in Cracow compared to other examples of city walls being transformed into urban parks. In Proceedings of the ECLAS Conference, Ghent, Belgium, 9-12 September 2018; Delarue, S., Dufour, R., Eds.; University College Ghent-School of Arts-Landscape \& Garden Architecture and Landscape Development: Ghent, Belgium, 2018; pp. 411-416.

24. Bimler, K. Die Schlesischen Massiven Wehrbauten, Bd. 1-5; Komission Heydebrand-Verlag: Breslau, Poland, $1940-1944$.

25. Przyłęcki, M. Budowle i Zespoły Obronne na Ślasku; Towarzystwo Opieki nad Zabytkami: Warszawa, Poland, 1998.

26. Thullie, C. Zabytki Architektoniczne Ziemi Ślaskiej na tle Rozwoju Architektury w Polsce; Wydawnictwo "Śląsk": Katowice, Poland, 1965.

27. Chrzanowski, T.; Kornecki, M. Sztuka Ślasska Opolskiego, od Średniowiecza do Końca w. XIX; Wydawnictwo Literackie: Kraków, Poland, 1974.

28. Adamska, M.E. Transformacie Rynków Średniowiecznych Miast Śląska Opolskiego od XIII Wieku do Czasów Współczesnych. Przerwane Tradycje, Zachowane Dziedzictwo, Nowe Narracje; Politechnika Opolska: Opole, Poland, 2019.

29. Piechaczek, B. Średniowieczne Kamienne Obwarowania Miast Opolszczyzny do Końca XV Wieku. Ph.D. Thesis, Katolicki Uniwersytet Lubelski Jana Pawła II, Lublin, Poland, 2006. 
30. Przybyłok, A. Mury Miejskie na Górnym Śląsku w Późnym Średniowieczu. Ph.D. Thesis, Uniwersytet Łódzki, Łódź, Poland, 2014.

31. Legendziewicz, A. Selected city gates in Silesia-Research issues. Technol. Trans. 2019, 3, 71-103. [CrossRef]

32. Legendziewicz, A. Brama Grobnicka (zwana Klasztorną) w Głubczycach w świetle badań architektonicznych i ikonograficznych. In Opolski Informator Konserwatorski 2015; Wojewódzki Urząd Ochrony Zabytków w Opolu: Opole, Poland, 2015 ; pp. 103-112.

33. Legendziewicz, A. Architektura bram miejskich Głogówka od XIV do XX wieku. Kwart. Opol. 2018, 4, 105-120.

34. Legendziewicz, A. Mury miejskie Kluczborka—od średniowiecza do współczesności. In Opolski Informator Konserwatorski 2015; Wojewódzki Urząd Ochrony Zabytków w Opolu: Opole, Poland, 2015; pp. 113-121.

35. Legendziewicz, A. Badania architektury Grodkowa. Średniowieczne fortyfikacje miejskie. In Z dziejów Grodkowa i ziemi grodkowskiej, p. 2; Urząd Miejski w Grodkowie: Grodków, Poland, 2015; pp. 67-88.

36. Wilkaniec, A.; Wichrowski, M. (Eds.) Fortyfikacje w Przestrzeni Miasta; Uniwersytet Przyrodniczy w Poznaniu: Poznań, Poland, 2006.

37. Przyłęcki, M. Miejskie Fortyfikacje Średniowieczne na Dolnym Śląsku. Ochrona, Konserwacja, Ekspozycja 1850-1980; PP PKŻ: Warszawa, Poland, 1987.

38. Adamska, M.E. Średniowieczne układy urbanistyczne miast Ślaska Opolskiego-Stan zachowania i rewitalizacja. Przeglad Bud. 2013, 3, 15-19.

39. Series of Publications Issued by PKN ICOMOS. Available online: http://www.icomos-poland.org/pl/publikacje.html (accessed on 15 March 2021).

40. Górski, A. (Ed.) Obwarowania miast. Problematyka ochrony, konserwacji, adaptacji i ekspozycji. In Proceedings of the International Scientific Conference, Kożuchów, Poland, 28-30 April 2010; Towarzystwo Przyjaciół Ziemi Kożuchowskiej: Kożuchów, Poland, 2010.

41. Transnational Model of Sustainable Protection and Conversation of Historic Ruins: Best Practices Handbook; Lublin University Of Technology: Lublin, Poland, 2020.

42. Cydzik, J. Przebudowa zabytkowego ośrodka staromiejskiego na przykładzie miasta Paczkowa. Ochr. Zabytk. 1961, 14, 75-92.

43. Steinborn, B. Otmuchów i Paczków; Zakład Narodowy im. Ossolińskich: Wrocław, Poland, 1961.

44. Dziewulski, W.; Hawranek, F. Opole Monografia Miasta; Instytut Śląski w Opolu: Opole, Poland, 1992.

45. Eysmonty, R.; Goliński, M. (Eds.) Namysłów. In Atlas Historycznych Miast Polskich, t IV, Ślask, Zeszyt 11; Instytut Archeologii i Etnologii PAN: Wrocław, Poland, 2015.

46. Borkowski, M.; Czapliński, M.P. Biała-Historia i Współczesność; Instytut Ślaski: Opole-Biała, Poland, 2011.

47. Meisner, J. (Ed.) Byczyny Przeszłość i Dzień Dzisiejszy; Instytut Śląski w Opolu: Opole, Poland, 1988.

48. Chrzanowski, T. Głogówek; Zakład Narodowy im. Ossolińskich: Wrocław, Poland, 1977.

49. Adamska, M. Rewaloryzacja starego miasta w Głubczycach. Zesz. Nauk. Politech. Opol. Ser. Bud. 1998, 43, 132-149.

50. Cimała, B. Kluczbork-Dzieje Miasta; Instytut Śląski w Opolu: Opole, Poland, 1992.

51. Chrzasszcz, J. Historia Miasta Krapkowice na Górnym Śląsku od 1914; Sady: Krapkowice, Poland, 2011.

52. Heffner, K. Ujazd—historia i Wspótczesność; Instytut Śląski w Opolu: Opole, Poland, 1990.

53. Inwentarz Zespołu PP PKZ Oddział Wrocław, Zespół Pracowni Dokumentacji Naukowo-Historycznej PP PKZ. Available online: https://www.nid.pl/pl/Regiony/Dolnoslaskie/Wykaz\%20dokumentacji/01_PP\%20PKZ\%20Wroc\%C5\%82aw\%20 Pracownia\%20Dokumentacji\%20Naukowo-Historycznej.pdf (accessed on 8 June 2021).

54. Dziennik Ustaw, Poz. 1240, Rozporządzenie Prezydenta Rzeczypospolitej Polskiej z Dnia 22 Października 2012 r. w Sprawie Uznania za Pomnik Historii Paczków—Zespół Staromiejski ze Średniowiecznym Systemem Fortyfikacji. Available online: https://nid. pl/pl/Informacje_ogolne/Zabytki_w_Polsce/Pomniki_historii/Lista_miejsc/Paczk\%C3\%B3w_rozporz\%C4\%85dzeenie.pdf (accessed on 15 October 2020).

55. Pudełko, J. Zagadnienia Wielkości Powierzchni Średniowiecznych Miast Śląskich; Zakład Narodowy im. Ossolińskich: Wrocław, Poland, 1967.

56. Eysymontt, R. Kod Genetyczny Miasta. Średniowieczne Miasta Lokacyjne Dolnego Ślaska na tle Urbanistyki Europejskiej; Via Nova: Wrocław, Poland, 2009.

57. Bahlcke, J. Górny Śląsk—studium przypadku powstania: Regionów historycznych, wyobrażeń o obszarach kulturowych, histograficznych koncepcji przestrzeni. In Historia Górnego Ślaska. Polityka, Gospodarka i Kultura Europejskiego Region; Bahlcke, J., Gawrecki, D., Kaczmarek, R., Eds.; Dom Współpracy Polsko-Niemieckiej: Gliwice, Poland, 2011; pp. 17-37.

58. Główny Urząd Statystyczny (GUS)—Central Statistical Office of Poland; Local Data Bank. Available online: https://bdl.stat.gov. $\mathrm{pl} / \mathrm{BDL} /$ start (accessed on 11 October 2020).

59. Raport o Stanie Środowiska Województwa Opolskiego 2020. Główny Inspektorat Ochrony Środowiska, Departament Monitoringu Środowiska, Regionalny Wydział Monitoringu Środowiska w Opolu: Opole, Poland, 2020. Available online: http: / / www.gios. gov.pl/images/dokumenty/pms/raporty/stan_srodowiska_2020_opolskie.pdf (accessed on 24 January 2021).

60. Program Ochrony Środowiska Województwa Opolskiego na Lata 2012-2015 z Perspektywa do Roku 2019. Available online: https: / / www.opolskie.pl/program-ochrony-srodowiska / (accessed on 24 January 2021).

61. Sustainable Development Report 2020. Available online: https:/ / dashboards.sdgindex.org/rankings (accessed on 24 January 2021).

62. Kapera, I. Rozwój Zrównoważony Turystyki. Problemy Przyrodnicze, Społeczne i Gospodarcze na Przykładzie Polski; Oficyna Wydawnicza AFM: Kraków, Poland, 2018. 
63. Bąk, I.; Matlegiewicz, M. Przestrzenne zróżnicowanie atrakcyjności turystycznej w Polsce w 2008 roku. In Zeszyty Naukowe Uniwersytetu Szczecińskiego. Ekonomiczne Problemy Ustug 2010, 52 Potencjał Turystyczny. Zagadnienia Przestrzenne; Wydawnictwo Naukowe Uniwersytetu Szczecińskiego: Szczecin, Poland, 2012; pp. 57-67.

64. Wiśniewska, A. Ocena rozwoju turystyki zrównoważonej w polskich regionach. Gospodarka w Praktyce i Teorii 2017, 49, 83-92. [CrossRef]

65. von Rohscheidt, A.M. Turystyka Kulturowa. Fenomen, Potencjat, Perspektywa, 3rd ed.; GWSHM: Gniezno, Poland, 2016.

66. Potocka, I. Atrakcyjność turystyczna i metody jej identyfikacji. In Uwarunkowania i Plany Rozwoju Turystyki, Tom III, Walory $i$ Atrakcje Turystyczne, Potencjał Turystyczny, Plany Rozwoju Turystyki; Młynarczyk, S., Zajajdacz, A., Eds.; Wydawnictwo Naukowe Uniwersytetu im. Adama Mickiewicza w Poznaniu: Poznań, Poland, 2009; pp. 19-31.

67. Brezovec, T.; Bruce, D. Tourism Development: Issues for Historic Walled Towns. Management 2009, 4, 101-114.

68. Tülek, B.; Atik, M. Walled towns as defensive cultural landscapes: A case study of Alanya-A walled town in Turkey. WIT Trans. Environ. 2014, 143, 231-242. [CrossRef]

69. Analizy Statystyczne. Ochrona Środowiska 2020/Statistical Analyses. Environment 2020; Główny Urząd Statystyczny/Statistics: Warszawa, Poland, 2020. Available online: https:/ / stat.gov.pl/obszary-tematyczne/srodowisko-energia/srodowisko/ochronasrodowiska-2020,1,21.html (accessed on 25 January 2021).

70. Von Wrede, C.F. Kriegs-Karte von Schlesien, 1747-1753; Staatsbibliothek zu Berlin, Kartenabteilung, Sygn. 15060; Lengenfelder, H (Verlag): München, Germany, 1992.

71. Wernher, F.B. Silesia in Compendio seu Topographia das ist Praesentatio und Beschreibung des Herzogthums Schlesiens [ ... ] Pars I. 1750-1800, BUWr Oddział Rękopisów. Available online: https://www.bibliotekacyfrowa.pl/dlibra/publication/8092 /edition/15414 (accessed on 15 October 2020).

72. Wernher, F.B. Scenographia Urbium Silesiae, Nürnberg, 1737-1752, BUWr Oddział Rękopisów. Available online: https:// bibliotekacyfrowa.pl/publication/3022 (accessed on 15 October 2020).

73. Sowińska-Świerkosz, B.N.; Michalik-Śnieżek, M. The Methodology of Landscape Quality (LQ) Indicators Analysis Based on Remote Sensing Data: Polish National Parks Case Study. Sustainability 2020, 12, 2810. [CrossRef]

74. Sowinska-Swierkosz, B.N.; Chmielewski, T.J. A new approach to the identification of Landscape Quality Objectives (LQOs) as a set of indicators. J. Environ. Manag. 2016, 184, 596-608. [CrossRef]

75. Myczkowski, Z. Kryteria waloryzacji krajobrazów Polski—propozycja systematyki. In Identyfikacja i Waloryzacja KrajobrazówWdrażanie Europejskiej Konwencji Krajobrazowej; Generalna Dyrekcja Ochrony Środowiska: Warszawa, Poland, 2020 ; pp. 64-73.

76. Fornal-Pieniak, B.; Żarska, B. Metody waloryzacji krajobrazowej na potrzeby turystyki i rekreacji. Acta Sci. Pol. 2014, 13, 3-9.

77. Czarnecki, W. Planowanie Miast i Osiedli, T.I. Wiadomości Ogólne. Planowanie Przestrzenne; PWN: Warszawa, Poland, 1965.

78. Jedwab, R.; Johnson, N.D.; Koyama, M. Medieval cities through the lens of urban economics. Reg. Sci. Urban Econ. 2020. [CrossRef]

79. Syperka, J. Dzieje gospodarcze Górnego Śląska w średniowieczu. In Historia Górnego Śląska. Polityka, Gospodarka i Kultura Europejskiego Regionu; Bahlcke, J., Gawrecki, D., Kaczmarek, R., Eds.; Dom Współpracy Polsko-Niemieckiej: Gliwice, Poland, 2011; pp. 295-308.

80. Bogucka, M.; Samsonowicz, H. Dzieje Miast i Mieszczaństwa w Polsce Przedrozbiorowej; Zakład Narodowy Imienia Ossolińskich Wydawnictwo: Wrocław, Poland, 1989; pp. 45-104.

81. Malik, R. Czeladź. Ze studiów nad budową i kształtem miasta średniowiecznego. Kwart. Arch. Urban. 2010, 55, 3-12.

82. Guzman, P. Assessing the sustainable development of the historic urban landscape through local indicators. Lessons from a Mexican World Heritage City. J. Cult. Herit. 2020, 46, 320-327.

83. Christopher Tweed, Margaret Sutherland, Built cultural heritage and sustainable urban development. Landsc. Urban Plan. 2007, 83, 62-69. [CrossRef]

84. Aminzadeh, B.; Khansefid, M. A case study of urban ecological networks and a sustainablecity: Tehran's metropolitan area. Urban Ecosyst. 2010, 13, 23-36. [CrossRef]

85. Balestrieri, M.; Ganciu, A. Greenways and Ecological Networks: Concepts, Differences, Similarities. Agric. Res. Technol. 2017, 12, 0011-0013. [CrossRef]

86. Środulska-Wielgus, J.; Staniewska, A.; Łakomy, K.; Wielgus, K. The historical elements of Kraków's green system-protection challenges for landscape planning in the 21st century. In Proceedings of the 5th Fábos Conference on Landscape and Greenway Planning, Budapest, Hungary, 1 July 2016; Jombach, S., Ed.; Szent István University, Department of Landscape Planning and Regional Development: Budapest, Hungary, 2016; pp. 439-446.

87. Raszeja, E.; Gałecka-Drozda, A. Współczesne interpretacje poznańskiego systemu zieleni w kontekście strategii miasta zrównoważonego. Stud. Miej. 2015, 19, 75-86.

88. Niedźwiecka-Filipiak, I.; Rubaszek, J.; Potyrała, J.; Filipiak, P. The Method of Planning Green Infrastructure System with the Use of Landscape-Functional Units (Method LaFU) and its Implementation in the Wrocław Functional Area (Poland). Sustainability 2019, 11, 394. [CrossRef]

89. Xing, Y.; Brimblecombe, P. Traffic-derived noise, air pollution and urban park design. J. Urban Des. 2020, 25, 590-606. [CrossRef]

90. Wang, S.; Jiang, Y.; Xu, Y.; Zhang, L.; Li, X.; Zhu, L. Sustainability of Historical Heritage: The Conservation of the Xi' an City Wall. Sustainability 2019, 11, 740. [CrossRef] 
91. Karta Ochrony Historycznych Ruin Przyjęta Uchwałą Walnego Zgromadzenia Członków PKN ICOMOS w Dniu 4 Grudnia 2012 r. Available online: http:/ /www.icomos-poland.org/pl/dokumenty/uchwaly/130-karta-ochrony-historycznych-ruin.html (accessed on 29 January 2021).

92. Trochonowicz, M. Obiekty murowe w ruinie. Wpływ czynników degradujących na ich zachowanie. In Ochrona, Konserwacja i Adaptacja Zabytkowych Murów: Trwała Ruina II: Problemy Utrzymania i Adaptacji; Szmygin, B., Ed.; Lubelskie Towarzystwo Naukowe, Polski Komitet Narodowy ICOMOS; Politechnika Lubelska: Lublin, Poland, 2010; pp. 172-184.

93. Trochonowicz, M.; Klimek, B.; Lisiecki, D. Biological corrosion and vegetation in the aspect of permanent ruin. Bud. Archit. 2018, 17, 17-26. [CrossRef]

94. Report on Current State-of-Art of Use and Re-Use of Medieval Ruins; Interreg Central Europa, Version 2, 12/2017. Available online: https: / / www.interreg-central.eu/Content.Node/RUINS/D.T2.1.1---Report-on-the-current-state-of-art-on-contempo1-pdf (accessed on 10 February 2021).

95. Ashworth, G.J.; Bruce, D.M. Town Walls, Walled Towns and Tourism: Paradoxes and paradigms. J. Herit. Tour. 2009, 4, $299-314$. [CrossRef]

96. Transforming Our World: The 2030 Agenda for Sustainable Development. Available online: https://sdgs.un.org/2030agenda (accessed on 21 May 2020).

97. Walter, G.R. Economics, Ecology-Based Communities, and Sustainability. Ecol. Econ. 2002, 42, 81-87. [CrossRef]

98. Hampton, M.P. Heritage, local communities and economic development. Ann. Tour. Res. 2005, 32, 735-759. [CrossRef] 